\title{
Philadelphia-Negative Chronic Myeloproliferative Neoplasms during the COVID-19 Pandemic: Challenges and Future Scenarios
}

\author{
Francesca Palandri $^{1}$ (D), Massimo Breccia ${ }^{2}(\mathbb{D})$, Valerio De Stefano ${ }^{3, *(D)}$ and Francesco Passamonti $^{4}$ \\ 1 IRCCS Azienda Ospedaliero-Universitaria di Bologna, Istituto di Ematologia "Seràgnoli", \\ 40138 Bologna, Italy; francesca.palandri@unibo.it \\ 2 Department of Translational and Precision Medicine, Azienda Ospedaliera Policlinico Umberto I, \\ Sapienza University, 00185 Rome, Italy; breccia@bce.uniroma1.it \\ 3 Section of Hematology, Department of Radiological and Hematological Sciences, \\ Catholic University School of Medicine, Fondazione Policlinico Universitario Agostino Gemelli IRCCS, \\ 00168 Rome, Italy \\ 4 Department of Medicine and Surgery, University of Insubria, ASST Sette Laghi, 21100 Varese, Italy; \\ francesco.passamonti@uninsubria.it \\ * Correspondence: valerio.destefano@unicatt.it
}

Citation: Palandri, F.; Breccia, M.; De Stefano, V.; Passamonti, F.

Philadelphia-Negative Chronic

Myeloproliferative Neoplasms during the COVID-19 Pandemic: Challenges and Future Scenarios. Cancers 2021, 13, 4750. https://doi.org/10.3390/ cancers13194750

Academic Editor: Marco Pizzi

Received: 6 August 2021

Accepted: 17 September 2021

Published: 23 September 2021

Publisher's Note: MDPI stays neutral with regard to jurisdictional claims in published maps and institutional affiliations.

Copyright: (c) 2021 by the authors. Licensee MDPI, Basel, Switzerland. This article is an open access article distributed under the terms and conditions of the Creative Commons Attribution (CC BY) license (https:// creativecommons.org/licenses/by/ $4.0 /)$.
Simple Summary: Little information has been reported about the impact of the COVID-19 pandemic in Philadelphia-negative chronic myeloproliferative neoplasms (MPN). In this review, we summarize the knowledge about MPN clinical management, including cytoreductive and antiplatelet/anticoagulant therapy, thrombotic risk, prognosis, and vaccination strategies at the time of COVID-19.

Abstract: An outbreak of severe acute respiratory syndrome coronavirus 2 (SARS-CoV2) started in December 2019 in China and then become pandemic in February 2020. Several publications investigated the possible increased rate of COVID-19 infection in hematological malignancies. Based on the published data, strategies for the management of chronic Philadelphia-negative chronic myeloproliferative neoplasms (MPNs) are provided. The risk of severe COVID-19 seems high in MPN, particularly in patients with essential thrombocythemia, but not negligible in myelofibrosis. MPN patients are at high risk of both thrombotic and hemorrhagic complications and this must be accounted in the case of COVID-19 deciding on a case-by-case basis. There are currently no data to suggest that hydroxyurea or interferon may influence the risk or severity of COVID-19 infection. Conversely, while the immunosuppressive activity of ruxolitinib might pose increased risk of infection, its abrupt discontinuation during COVID-19 syndrome is associated with worse outcome. All MPN patients should receive vaccine against COVID-19; reassuring data are available on efficacy of mRNA vaccines in MPNs.

Keywords: coronavirus; COVID-19; MPNs; cancer; pandemic

\section{Introduction}

\subsection{Overview of Coronavirus Pandemic}

Alpha and beta Coronaviruses (CoVs) are a subfamily of large and enveloped viruses that are known to infect humans, mainly through respiratory transmission [1,2]. Severe acute respiratory syndrome coronavirus (SARS-CoV) and Middle East respiratory syndrome coronavirus (MERS-CoV) have caused widespread concern resulting in epidemics with significant morbidity and mortality in 2002 and in 2012, respectively [3,4].

In December 2019, a novel coronavirus was identified to be responsible for unidentified pneumonia outbreaks in Wuhan, Hubei Province, China [5]. Since the genomic sequence of the current virus is closer to that of SARS-CoV than that of MERS-CoV, the 
nomenclature SARS-CoV-2 was given to the causative pathogen of coronavirus disease 2019 (COVID-19) [6].

The incubation period of COVID-19 is between 1 and 14 days, mostly between 3 and 7 days. Transmission occurs primarily via respiratory droplets and close contacts. The SARSCoV-2 infection may be responsible for different outcomes ranging from asymptomatic infection $(6.4 \%)$, mild to moderate cases $(79.6 \%)$, severe $(5.3 \%)$, critical $(7.3 \%)$ and fatal cases (1.4\%) [7]. Mild and moderate cases are mainly characterized by symptoms related to upper airways infection (fever, fatigue and dry cough, sore throat) and inflammation (myalgia, arthralgia and headache). Severe and critical cases are characterized by multiple complications including respiratory distress, thromboses, sepsis, acute kidney injury, acute cardiac injury and multi-organ dysfunction.

Along with clinical stages, also a progressive coagulopathy may be observed in COVID-19 patients. Stage 1 (mild infection) is characterized by mildly systemic coagulopathy. Stage 2 includes moderate and severe cases and is characterized by pulmonary inflammation and coagulopathy with localized microthrombi. Stage 3 includes critical and fatal cases and is characterized by a severe hyperimmune syndrome and systemic coagulopathy associated with thrombocytopenia and high risk of severe thrombosis (pulmonary embolism, deep vein thrombosis) [8].

\subsection{Impact of Coronavirus Pandemic on Cancer Patients}

With around 161,310,781 infected people and over 3,347,409 deaths registered worldwide between February 2020 and June 2021, the COVID-19 pandemic is an emergency of major international concern $[9,10]$.

The detrimental impact of a cancer diagnosis on SARS-CoV-2 infection was rapidly observed in a study on the Chinese population, in which $1 \%$ of patients with COVID-19 had cancer, whereas the incidence of cancer was $0.29 \%$. While epidemiological findings could be related to a closer medical follow-up in cancer patients, more severe respiratory complications were ascertained in this cohort as compared with patients without cancer ( $39 \%$ vs. $8 \%$, respectively; $p=0.0003$ ) and a history of chemotherapy in the month preceding infection was negatively associated with survival (odds ratio $5.34,95 \%$ CI $1.80-16.18$; $p=0.0026$ ) [11-13]. A recent meta-analysis including 41 studies with 16,495 COVID-19 patients observed that proportion of hypertension (OR: 1.98, 95\% CI: 1.62-2.42), diabetes (OR: 2.04, 95\% CI: 1.67-2.50), cardiovascular disease (OR: 2.78, 95\% CI: 2.00-3.86) and cancer (OR: 1.75, 95\% CI: 1.40-2.18) were significantly higher in patients with severe viral infection, confirming that comorbidities and cancer may affect the outcome of SARS-CoV-2 infection [14].

Philadelphia-negative (Ph-) chronic myeloproliferative neoplasms (MPNs) are clonal disorders including polycythemia vera (PV), essential thrombocythemia (ET) and myelofibrosis (MF), primary MF (PMF) or secondary to ET or PV (PPV/PET-MF) [15]. These chronic cancers are characterized by increased thrombotic risk, progressive splenomegaly, debilitating systemic symptoms and reduced survival [16].

Infections are frequently reported in MPNs, representing the ultimate cause of death in approximately $10 \%$ of patients $[17,18]$. Infections are primarily bacterial $(78 \%)$ but viral $(11 \%)$ and fungal $(2 \%)$ infections can also develop [17].

Infectious risk in MPNs is mainly caused by deregulation of key mediators of the immune system. In particular, monocytes/macrophages, $\mathrm{T}$ cells, natural killers and myeloid-derived suppressor cells are often characterized by numerical and/or functional abnormalities [19-25].

The use of agents with immunosuppressive activity, including the JAK1/2 inhibitor ruxolitinib (RUX) may further increase the risk of infections [17,26-34] (Figure 1).

In a short time, the global research community has made an impressive effort to report the different characteristics of COVID-19 while taking care of patients. However, information on SARS-CoV-2 infection impact on management and outcome of MPN patients is scarce. To understand these concerns, a detailed search of the literature was 
conducted using PubMed (US National Library of Medicine and the National Institutes of Health) and Web of Science (Thomas Reuters Online Academic Citation Index), with publication dates ranging from 2000 to June 2021. To ensure an extensive range of publications were identified, broad search terms for ET, PV, MF, COVID-19, SARS-CoV-2, vaccine and clinical/epidemiological variables (e.g., incidence, prevalence, frequency, diagnosis, pathogenesis, infections, thrombosis, bleedings, complications, survival, outcome) were utilized. Furthermore, we reviewed the literature cited in the identified papers.

Based on this research, we have outlined currently available data to answer the most frequently asked questions related to the impact of the COVID-19 pandemic on MPN clinical management, including cytoreductive and antiplatelet/anticoagulant therapy, thrombotic risk, prognosis and vaccination strategies.

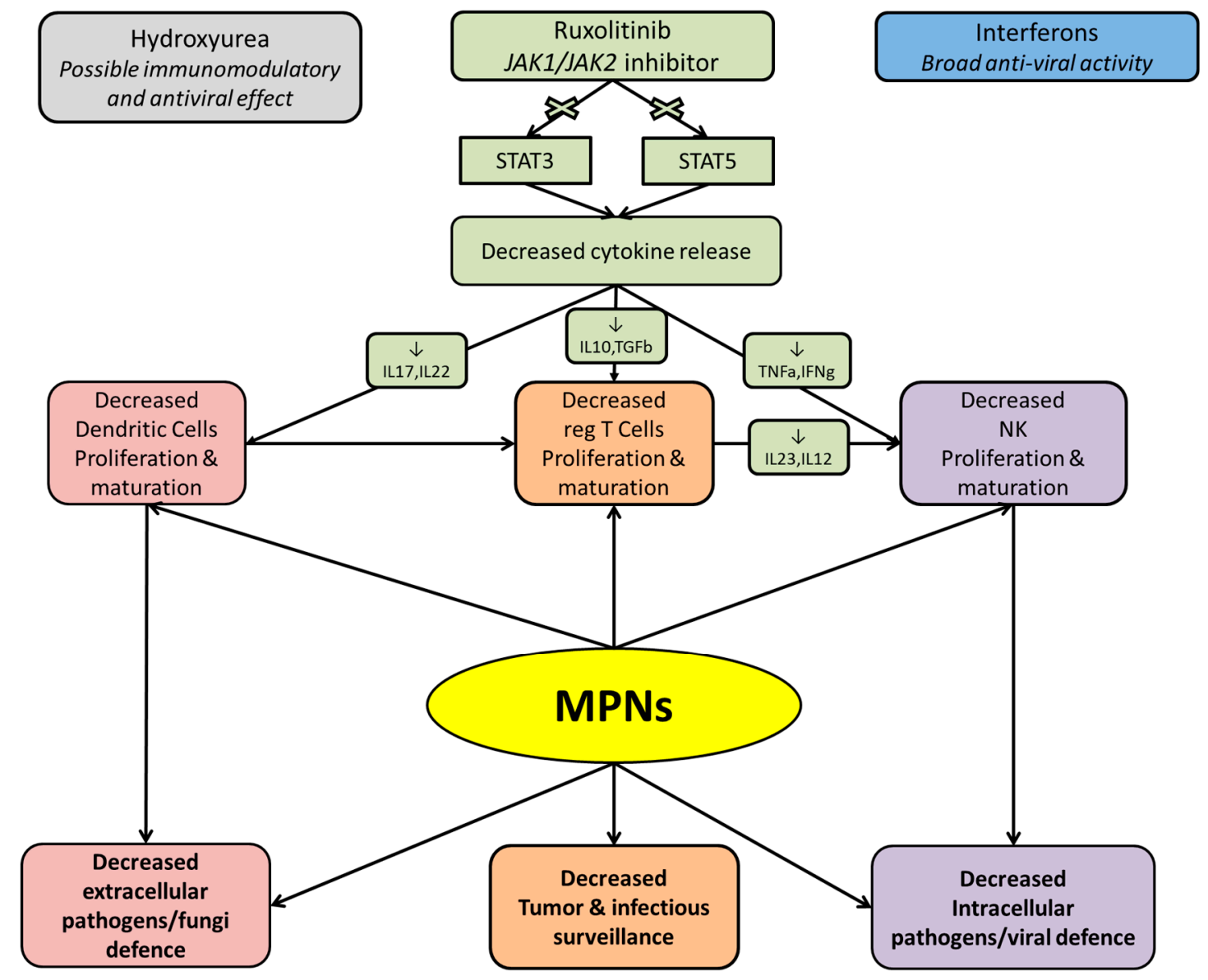

Figure 1. Pathways of immunodeficiency in patients with myeloproliferative neoplasms (MPN) and role of the JAK1/2 inhibitor ruxolitinib.

\section{Is the Risk of Infection and Severe SARS-CoV-2 Illness Higher in MPN Patients?}

Infections are one of the main causes of morbidity and mortality in patients with MPNs. In a Swedish population-based study, the risk of dying of infection was 2.5-fold, 4.6-fold and 10.4-fold higher in patients with ET, PV and MF, respectively, compared to age- and sex-matched healthy controls [18]. In addition, in a German-Italian patient-reported pilot study, MF diagnosis and ruxolitinib therapy were associated with higher infectious risk [35]. Among MF patients, worse disease status in terms of higher International Prognostic Score System (IPSS) risk and large ( $\geq 10 \mathrm{~cm}$ below costal margin) splenomegaly were significantly associated with infectious risk [17]. 


\subsection{Risk of Infection SARS-CoV-2 in MPN Patients}

In 271 German MPN patients, no COVID-19 infection or positive SARS-CoV-2 test result was reported during the survey period and only $1 \%$ of people in close contact with patients tested positive for SARS-CoV-2. However, a medical mask was used by almost all patients and $26 \%$ had spontaneously quarantined themselves. The observed low incidence of COVID-19 infections in this relatively small patient population may be related to random variations in infection rates. Nonetheless, this survey suggests that adherence to basic prevention rules can reduce the risk of infection [36]. In a prospective study on 257 MPN patients from Canada, only 1\% contracted COVID-19 infection, much less than would be expected given provincial infection rates [37]. In another survey conducted on $964 \mathrm{MPN}$ patients from United Kingdom, $96.1 \%$ of respondents reported no previous confirmed COVID-19 infection; notably, 91.5\% of respondents reported COVID-19 vaccination when they had the opportunity and only $0.8 \%$ of respondents declined offer of COVID-19 vaccination [38].

Between February and April 2020, an Italian survey involved 34 blood centers and a cohort of 13,248 Ph- MPN patients. A total of 36 patients had been infected with COVID-19 (33.6\% of patients tested but $0.002 \%$ of the entire cohort). Of these, $13(36 \%)$ were asymptomatic, 13 had had mild flu-like symptoms (36\%) and 10 had developed pneumonia (four patients required invasive ventilation). The mortality rate from COVID-19 was 22\% (34\% of symptomatic patients) [39]. In the registry of the American Society of Hematology, $92(9.7 \%)$ out of 947 hematology patients affected by COVID-19 syndrome had a Philadelphia-negative or positive myeloproliferative neoplasm [40].

According to the aforementioned reports, the risk of getting the SARS-CoV-2 infection seems not elevated in MPNs. However, such conclusion can be weakened by the relatively small number of patients investigated. A nation-wide database of patient electronic health records of 73 million patients in the US was analyzed for COVID-19 and eight major types of hematologic malignancies (including 121,200 ET patients and 134 72,150 PV patients, PMF was not included in the analysis). Patients with hematologic malignancies had increased odds of COVID-19 infection compared with patients without hematologic malignancies for both all-time diagnosis (adjusted odds ratio, AOR, 2.27) and recent diagnosis in the past year (AOR 11.91). ET produced the strongest effect, after acute lymphoid leukemia, for both all-time diagnosis (AOR 4.29) and recent diagnosis (AOR 20.65). PV patients had a OR for COVID-infection of 1.43 and 4.89 (all-time diagnosis and recent diagnosis, respectively [41].

\subsection{Mortality for SARS-CoV-2 Infection in MPN Patients}

In the cohort collected by the Italian Hematology Alliance on COVID-19, that included 536 patients admitted to 66 Italian hospitals between 25 February and 18 May 2020, with symptomatic COVID-19, 15\% had an MPN [42]. The same study highlighted that the presence of any hematological neoplasms significantly worsened survival in case of COVID-19, with a standardized mortality ratio of 3.72 in hematological patients under 70 years of age compared to the Italian healthy population. In addition, having COVID-19 significantly impaired survival in patients with hematological malignancies (standardized mortality ratio of 41.3 compared to hematological non-COVID-19 population) [42].

A population-based registry study from Spain collected 883 patients with hematologic malignancies and COVID-19 syndrome. Patients with acute myeloid leukemia (AML, 2.22 versus non-Hodgkin's lymphoma, NHL) and active antineoplastic treatment with monoclonal antibodies (2.02) were associated with higher mortality. In contrast, but not surprisingly, lower mortality was observed in patients with Ph-negative MPN compared to AML and NHL patients (0.33) [43]. In a survey on 77 patients from the United Kingdom with MPN and COVID-19 (82\% hospitalized, 35\% with MF), the case fatality rate among the inpatients was 52\%. In a comparison cohort of 60,430 COVID-19 hospitalized patients, the rate of mortality was $28 \%$ [44]. 
In the European Leukemia Net (ELN) International Study on MPN and COVID-19, $175 \mathrm{MPN}$ patients (PV $n=46$; ET $n=51$; pre-fibrotic MF $n=18$; PMF $n=60$ ) who developed COVID-19 from 15 February to 31 May 2020 were collected in 37 European hematology Centers. During the acute phase of the infection, in-hospital mortality affected $27.4 \%$ of patients and the most vulnerable MPN subgroup was overt PMF (mortality 48\%); notably, the proportion of patients admitted to Intensive Care Unit (ICU) was 10.9\%. The diagnosis of ET, PV and pre fibrotic-PMF did not influence the proportion of survivors versus nonsurvivors [45].

Finally, a recent review of 13 cohort or population studies reported that patients with a hematological malignancy, especially those diagnosed recently and with myeloid neoplasia including myeloproliferative disorders, are at increased risk of death with COVID-19 compared to the general population [46].

Post-COVID-19 related consequences including vascular complications and clonal evolution into MF, myelodysplasia (MDS) and acute myeloid leukemia (AML) were also explored in 125 of the 175 patients (71\%) enrolled in MPN-COVID ELN study, who survived to the acute phase of infection [47]. Notably, deaths occurred in eight patients after 9 months, with a $9 \%$ probability of death. The event-free survival (thrombosis, cancer and death) was $66 \%$ in the 125 patients followed for a median of 6 months post-COVID-19. Overall, these data indicate that the health consequences of COVID-19 extend beyond acute infection and suggest careful surveillance in all patients with MPNs.

Compared to the healthy population, MPN patients are at higher risk for all infections. The likelihood of having COVID-19 seems higher in MPNs. MF are less able to recover from COVID19. MPN patients require aggressive infection prevention strategies with strict adherence to coronavirus safety protocols. There is some evidence that this policy can significantly reduce the risk of infection. After COVID-19 infection, MPN patients should receive adequate clinical and laboratory monitoring.

\section{Should Antiplatelet or Anticoagulant Therapy Be Changed in MPN Patients during the SARS-CoV-2 Pandemic?}

A recent international survey analyzed $442 \mathrm{MPN}$ patients receiving direct oral anticoagulants (DOAC) because of a concomitant diagnosis of atrial fibrillation or a history of venous thromboembolism (VTE) [48]; the overall rate of thrombosis and major bleeding was comparable to that previously reported in MPN patients receiving vitamin $\mathrm{K}$ antagonists (VKA) [49], furnishing indirect evidence of a similar efficacy and safety. Major bleeding was more frequent in patients receiving dabigatran or with diagnosis of MF [49]. Therefore, DOAC could represent a possible alternative to VKA for antithrombotic prophylaxis given the advantage in ease of administration and improved patient convenience. In the pandemic scenario, they can represent an alternative to VKA to reduce the need for hospital visits for INR control.

The COVID-19 syndrome is known to be associated with coagulation disorders and increased risk of vascular events [50]. COVID-19-associated coagulopathy has prompted the use of standard supportive care measures and thromboembolic prophylaxis for critically ill hospitalized patients [51]. A multicenter retrospective study on 400 hospital-admitted COVID-19 patients receiving standard-dose prophylactic anticoagulation observed an overall thrombotic complication rate of $9.5 \%$, while the overall and major bleeding rates were $4.8 \%$ and $2.3 \%$, respectively [52].

In a cohort of $162 \mathrm{MPN}$ patients with SARS-CoV-2 infection (PV $n=42$; ET $n=48$; prefibrotic MF $n=16$; PMF $n=56$ ), 15 major thromboses (12 venous, 8 of which occurred in patients with ET) were collected. All but one patient were receiving low molecular weight heparin (LMWH) prophylaxis. The cumulative incidence of arterial and venous thromboembolic events adjusted for risk of death was $8.5 \%$ after 60 days of observation. At diagnosis of COVID-19, platelet counts were significantly lower $(p<0.0001)$ than at the last pre-COVID follow-up. The decline in platelet count was significantly higher in ET $(-23.3 \%, p<0.0001)$ than in PV $(-16.4 \%, p=0.1730)$ and was associated with a higher mortality rate $(p=0.0010)$ from pneumonia. Independent risk factors for thrombosis were 
ICU transfer (SHR $=3.73, p=0.029)$, neutrophil/lymphocyte ratio $(\mathrm{SHR}=1.1, p=0.001)$ and ET phenotype (SHR $=4.37, p=0.006)$ [53]. Seven out of 162 patients $(4.3 \%)$ developed major bleeding, particularly in the MF; these events were diagnosed later, i.e., starting 7-10 days after the onset of SARS-CoV-2 infection. Overall, the rate of thromboses seem to be higher in patients with ET that acquire SARS-CoV-2 infection (16.6\%), while in MPNCOVID patients, the rate of bleeding is high, but overall comparable to newly diagnosed non-COVID MPN patients and to non-MPN COVID patients [52,54-56].

In line with the recommendations contained in the latest ASH version of the international panel of MPN experts [57], all hospitalized MPN-COVID patients should receive prophylactic doses of LMWH. Operationally, the treatment of pre-fibrotic myelofibrosis does not differ much from that of ET [58] and the thrombotic risk is similar [59].

High-risk condition concerns hospitalized patients with MPN treated with both VKA or DOACs for pre-COVID-19 chronic atrial fibrillation or history of venous thromboembolism (VTE). Given the possible metabolic interaction of these drugs with most antiretroviral drugs on liver cytochromes, such as CYP2C9 and CYP3A4 [60], the advice is to replace oral anticoagulants with LMWH prophylaxis in hospitalized MPN-COVID patients [57].

In patients with pre-COVID-19 arterial thrombosis (transient ischemic attack, ischemic stroke, myocardial infarction, peripheral arterial thrombosis) or with percutaneous coronary intervention (PCI) (within $\leq 3$ months), it is strongly recommended not to discontinue antiplatelet drugs, unless clinical circumstances or hemorrhagic events prevent it [61].

There is no indication that patients with MPN should change antiplatelet or anticoagulant therapy if SARS-CoV-2 negative. For MPN patients with a new event requiring oral anticoagulation, DOAC instead of VKA might be taken into consideration to reduce in-hospital visits.

$M P N$ patients are at high risk of both thrombotic and hemorrhagic complications and this must be accounted in the case of COVID-19 deciding on a case-by-case basis and considering overall performance status, thrombotic/hemorrhagic risk and laboratory/hematology parameters. Switch from oral anticoagulation to LMWH may be considered in SARS-CoV-2 positive MPNs as platelet count can reduce promptly and for a lesser drug-drug interaction. The use of LMWH is recommended in all hospitalized COVID-19 MPN patients, in replacement of ongoing low-dose aspirin. LMWH should be added to ongoing aspirin in the case of pre-COVID-19 history of arterial thrombosis.

ET patients are at higher risk of thrombosis and need special clinical surveillance; the benefit of a combined treatment of LMWH and aspirin, given the possible role of platelets, should be investigated by ad hoc studies.

\section{Should Cytoreductive Therapy or Phlebotomies Management Be Changed during the SARS-CoV-2 Pandemic?}

In ET and PV, the major goal of therapy is to reduce thrombotic and hemorrhagic events and to monitor for disease progression including transformation into acute leukemia and myelofibrosis [62].

All patients with PV require phlebotomy to keep hematocrit (Hct) below $45 \%$ and once-daily low-dose aspirin, in the absence of contraindications [63]. There is no evidence that phlebotomy indications should be modified because of the COVID-19 pandemic. Strategies that may reduce the need for phlebotomies (i.e., increased water intake and/or start of cytoreduction) and in-hospital visits (i.e., decreased waiting time for phlebotomy through an online ticketing system; telehealth, rapid vaccination of health care professionals; increasing disinfection of all the contacting surfaces) should be implemented [64-66].

Cytoreductive therapies are indicated in PV and ET patients at high thrombotic risk of (age $\geq 60$ years and/or history of thrombotic event) and in selected low-risk patients [67-69].

Hydroxyurea/hydroxycarbamide (HU) is the most widely used cytoreductive agent in PV and ET [70-72]. Among HU-intolerant patients, less than 5\% develop a hematological toxicity (namely, absolute neutrophil count $<1.0 \times 10^{9} / \mathrm{L}$ or platelet count $<100 \times 10^{9} / \mathrm{L}$ or hemoglobin $<10 \mathrm{~g} / \mathrm{dL}$ at the lowest dose of $\mathrm{HU}$ required to achieve a complete or partial clinico-hematologic response) [73]. In the Continuation-PV trial that randomized 
early-stage PV patients to receive either hydroxyurea or ropeg-interferon $\alpha 2 b, 2 \%$ of both $\mathrm{HU}$ and interferon-treated patients had a grade 3 neutropenia without grade 4 events, which was reversible after drug temporary discontinuation or dose reduction [74].

Overall, immunosuppression related to HU therapy is infrequent, transitory and with no clinical relevance. Additionally, HU has an immunomodulatory effect in sickle cell anemia (SCA), which is, like COVID-19, a hyperinflammatory thrombogenic syndrome. The cytostatic effect of $\mathrm{HU}$ on CD4 and CD8 T cells may decrease the abnormal production of proinflammatory cytokines during COVID-19, reducing the severity of clinical symptoms. HU was also shown to exert an antiviral effect in human immunodeficiency virus (HIV) infections [75]. In vitro, HU inhibits viral DNA synthesis studies of HIV-infected lymphocytes and has a synergic activity with nucleoside reverse transcriptase inhibitors. Possibly, HU may also in COVID-19 attenuate viral load by decreasing CD4 $\mathrm{T}$ cell proliferation and preventing the exhaustion of CD8 T cells [76-78].

A recent Italian survey showed that HU was started in all ET and PV patients at high thrombotic risk by $82.6 \%$ of hematologists. Nonetheless, HU was started only if also cardiovascular risk factors were present in high-risk patients by $13 \%$ of treating hematologists [79].

Interferons (IFNs) has been shown to have therapeutic activity against MPNs and are indicated in the first and second-line therapy of ET and PV [16,80,81].

To date, no evidence of association between IFN therapy and the clinical course of SARS-CoV-2 infection in MPN patients has been reported. Rather, type 1 IFNs induce cell-autonomous antiviral immunity and their levels dramatically increase in response to viral infections [82]. Due to their broad antiviral activity, they are currently being tested for the treatment of early-stage COVID-19 infections [83,84].

Nonetheless, more than $50 \%$ of the Italian hematologists who responded to a GIMEMA survey declared to postpone IFN start after the resolution of the pandemic, possibly due to an increased number of blood tests and hematological visits required during the first period of treatment [79]. Conversely, during the pandemic most hematologists did not change the treatments that were already ongoing. Only a minority of the hematologists discontinued HU or IFN ( $2.2 \%$ and $5.6 \%$, respectively) and only $4.3 \%$ and $5.6 \%$ decreased their doses [79].

PV patients treated with phlebotomies should maintain their hematocrit target $<45 \%$ : any effort should be done to maintain this approach during the pandemic.

There are currently no data to suggest that hydroxyurea increases the risk of COVID-19. Therefore, it is believed that therapy should not be modified with dose reductions. On the contrary, it is considered appropriate to continue therapy to reduce the risk of frequent thrombotic events with COVID-19. In this sense, the use of hydroxyurea as prevention of thromboses has also been considered in other diseases such as sickle cell anemia during COVID-19 infection [85].

In patients that are under interferon therapy, no therapeutic modification is necessary during the COVID-19 pandemic since interferon does not increase the risk of getting SARS-CoV-2 infection. Even in case of overt COVID-19 infection, there is no evidence that this therapy should be modified.

\section{Ruxolitinib Use: From MPN Therapy to Control of SARS-CoV-2 Hyperimmune Syndrome}

Ruxolitinib (RUX) is the first-in-class JAK1/2 inhibitor and represents the standard front-line therapy for MF-related splenomegaly and symptoms. RUX is also approved for the treatment of inadequately controlled PV after hydroxyurea failure because of intolerance or resistance [86-93].

JAK1/2 inhibition decreases pro-inflammatory cytokines which causes the improvement of disease-related symptoms but also impairs immune function. Indeed, RUX use is associated with a number of abnormalities of adaptive and innate immunity [94] (Figure 1). Clinically, opportunistic and atypical infections have been described during RUX therapy $[17,26,95-105]$. Therefore, a systematic infectious screening is recommended before the start of ruxolitinib [106]. 
Ruxolitinib-induced decreased immunosurveillance was initially considered a risk factor for an increased chance of acquiring SARS-CoV-2 infection and/or developing a more severe COVID-19 syndrome in patients with MPNs [57]. However, subsequent evidence has demonstrated that RUX administration was not associated with reduced survival in patients affected by COVID-19 infections. Conversely, patients who discontinued RUX had a significantly worse prognosis compared to COVID-19 MPN patients that could continue RUX therapy during the infection. Ruxolitinib discontinuation is associated with an 8.51-fold increased risk of death at multivariable analysis $(p=0.037)$ [39].

Such data strongly suggests that discontinuation of ruxolitinib in the setting of COVID-19 infection may be deleterious and should be avoided if clinically feasible [57].

In a recent GIMEMA survey, most hematologists declared to have started RUX according to routine practice during the first pandemic wave, particularly in patients with MF. Before ruxolitinib start, $40.2 \%$ of the hematologists obtained a negative COVID-19 pharyngeal swab, while in case of flu-like symptoms, COVID-19 swab is performed by most hematologists. Overall, most (79.8\%) of the hematologists believed that ruxolitinib had no negative effect on COVID-19 infection, while $10.1 \%$ believed that the drug could have a negative influence in patients with MF and/or a more severe disease status. Conversely, $10.1 \%$ of hematologists anticipated a negative effect in all patients. In case of mild and moderate COVID-19 infection, $67 \%$ and $58.4 \%$ of treating hematologists would not stop or reduce ruxolitinib, respectively [79].

On the other hand, the ability of RUX to reduce the production of pro-inflammatory cytokines might have a beneficial effect on the course of COVID-19. Indeed, SARS-CoV-2 infection is associated to a cytokine storm syndrome triggered by dysregulated immune responses [107]. The cytokine storm includes a high inflammatory response with elevated levels of cytokines and immune cells that may cause organ dysfunction and in particular lung lesions, respiratory distress, multiple organ damage and death [108]. Cytokines regulate several cellular and immune processes controlled by the JAK/STAT pathway [109]. The IL6/JAK/STAT3 signaling pathway is a specific branch of the JAK/STAT pathway; IL6 is an essential pleiotropic cytokine produced by B cells, T cells, dendritic cells and macrophages able to generate an immune response or inflammation [110]. In the COVID-19 cytokine storm, IL6 is one of the most highly expressed cytokines: one of the main indicators of poor prognosis in SARS-CoV-2 infection is represented by elevated serum levels of IL6 [111].

As a result, different therapeutic strategies to treat COVID-19 related hyperinflammation include the use of JAK/STAT inhibitors (Table 1) [112]. However, the randomized phase III RUXCOVID study evaluating ruxolitinib on top of standard of care therapy in COVID-19 patients was prematurely closed, since it did not meet its primary endpoint (reduction of the number of hospitalizations for COVID-19).

In MPN patients who are SARS-CoV-2 negative during the pandemic, ruxolitinib should be started or continued with no modifications according to guidelines. A negative SARS-CoV-2 swab test is generally not requested before ruxolitinib start; however, obtaining the COVID-19 status might be useful. There is also no indication to modify ruxolitinib doses in patients with asymptomatic/mild COVID-19. However, a dose reduction of ruxolitinib may be temporarily performed to reduce drug-drug interactions worsening hematology parameters or patients' clinical status. To note, the discontinuation of ruxolitinib in MPNs with COVID-19, outside a clear indication, seems associated to a worse outcome and is discouraged [39]. 
Table 1. Summary on the use of ruxolitinib and other JAK2-inhibitors in the treatment of SARS-CoV-2 infection. SoC: Standard of Care.

\begin{tabular}{|c|c|c|c|c|c|}
\hline $\begin{array}{l}\text { JAK2- } \\
\text { Inhibitor }\end{array}$ & Locations & Study & $\begin{array}{l}\text { Stage of COVID-19 } \\
\text { Infection }\end{array}$ & Design & Therapy \\
\hline Ruxolitinib & $\begin{array}{c}\text { US, Argentina, Brazil, } \\
\text { Colombia, France, } \\
\text { Germany, Mexico, Peru, } \\
\text { Russia, Spain, Turkey, UK }\end{array}$ & $\begin{array}{l}\text { RUXCOVID, } \\
\text { NCT04362137 }\end{array}$ & $\begin{array}{l}\text { COVID-19 associated } \\
\text { cytokine storm requiring } \\
\text { hospitalization }\end{array}$ & $\begin{array}{l}\text { Phase } 3 \text {, randomized, } \\
\text { placebo-controlled }\end{array}$ & $\begin{array}{l}\text { RUX } 5 \text { mg BID + SOC } \\
\text { vs. PLACEBO + SOC }\end{array}$ \\
\hline Ruxolitinib & UK & $\begin{array}{l}\text { RAVEN, Eudract } \\
\text { 2020-001777-71 }\end{array}$ & $\begin{array}{l}\text { COVID-19 associated } \\
\text { cytokine storm requiring } \\
\text { hospitalization }\end{array}$ & $\begin{array}{c}\text { Phase } 4, \\
\text { non-randomized, } \\
\text { open label }\end{array}$ & RUX 5-20 mg BID \\
\hline Ruxolitinib & Danmark & $\begin{array}{c}\text { Eudract } \\
2020-001459-42\end{array}$ & $\begin{array}{l}\text { Severe COVID-19 } \\
\text { Infection }\end{array}$ & $\begin{array}{c}\text { Phase 2, } \\
\text { non-randomized, } \\
\text { open label }\end{array}$ & RUX 5-20 mg BID \\
\hline Ruxolitinib & Germany & $\begin{array}{c}\text { RuXoCoil, Eudract } \\
\text { 2020-001732-10 } \\
\text { NCT04359290 }\end{array}$ & $\begin{array}{l}\text { Severe lung injury } \\
\text { with ARDS }\end{array}$ & Single-arm, open label & RUX 5 mg BID \\
\hline Ruxolitinib & Germany & $\begin{array}{l}\text { RuxCoFlam, } \\
\text { Eudract } \\
2020-001481-11\end{array}$ & $\begin{array}{c}\text { Stage II/III COVID-19 } \\
\text { with defined } \\
\text { hyperinflammation }\end{array}$ & $\begin{array}{c}\text { Phase 2, } \\
\text { non-randomized, } \\
\text { open label }\end{array}$ & RUX 5-20 mg BID \\
\hline Ruxolitinib & China & $\begin{array}{l}\text { ChiCTR-OPN- } \\
2000029580\end{array}$ & $\begin{array}{l}\text { Severe COVID-19 } \\
\text { Infection }\end{array}$ & $\begin{array}{l}\text { Single blind } \\
\text { Randomized } \\
\text { Controlled }\end{array}$ & $\begin{array}{l}\text { RUX } 5 \text { mg BID in } \\
\text { combination with } \\
\text { mesenchymal stem } \\
\text { cells vs. SOC }\end{array}$ \\
\hline Ruxolitinib & US, Russian federation & $\begin{array}{l}\text { RUXCOVID- } \\
\text { DEVENT, } \\
\text { NCT04377620 }\end{array}$ & $\begin{array}{l}\text { Severe lung injury } \\
\text { with ARDS }\end{array}$ & $\begin{array}{l}\text { Phase } 3 \text {, randomized, } \\
\text { placebo-controlled }\end{array}$ & $\begin{array}{c}\text { RUX } 5 \text { mg BID + SOC } \\
\text { vs. RUX } 15 \mathrm{mg} \text { BID + } \\
\text { SOC vs. } \\
\text { PLACEBO + SOC }\end{array}$ \\
\hline Ruxolitinib & France & $\begin{array}{l}\text { JAKINCOV, } \\
\text { Eudract } \\
\text { 2020-001963-10, } \\
\text { NCT04366232 }\end{array}$ & $\begin{array}{l}\text { Severe COVID-19 } \\
\text { Infection }\end{array}$ & $\begin{array}{l}\text { Phase } 2 \text {, randomized, } \\
\text { open label }\end{array}$ & $\begin{array}{l}\text { Anakinra } 300 \mathrm{mg} \text { IV + } \\
\text { RUX } 5 \mathrm{mg} \text { BID vs. } \\
\text { Anakinra } 300 \mathrm{mg} \\
\text { IV+ PLACEBO }\end{array}$ \\
\hline Ruxolitinib & UK & $\begin{array}{c}\text { MATIS, } \\
\text { NCT04581954 }\end{array}$ & $\begin{array}{l}\text { mild or moderate } \\
\text { COVID-19 pneumonia }\end{array}$ & $\begin{array}{l}\text { multi-arm, } \\
\text { multi-stage, } \\
\text { randomised } \\
\text { controlled trial }\end{array}$ & $\begin{array}{c}\text { RUX 10mg BID Day 1-7 } \\
\text { and } 5 \text { mg BID Day } 8-14 \\
\text { vs. FOSTAMATINIB } \\
150 \mathrm{mg} \text { BID Day } 1-7 \\
\text { and } 100 \mathrm{mg} \text { BID Day } \\
8-14 \text { vs. SOC }\end{array}$ \\
\hline Pacritinib & US & $\begin{array}{l}\text { PRE-VENT, } \\
\text { NCT04404361 }\end{array}$ & $\begin{array}{l}\text { COVID-19 associated } \\
\text { cytokine storm requiring } \\
\text { hospitalization }\end{array}$ & $\begin{array}{c}\text { Phase } 3 \text {, randomized, } \\
\text { double-blind, } \\
\text { placebo-controlled }\end{array}$ & $\begin{array}{l}\text { Pacritinib + SOX vs. } \\
\text { Placebo + SOC }\end{array}$ \\
\hline
\end{tabular}

\section{Prevention of SARS-CoV2 Infection in MPN Patients: What Vaccines to Use, When and with What Precautions?}

Vaccines are considered the most promising approach to prevent SARS-CoV-2 infection and control the pandemic [113]. SARS-CoV-2 genome contains single-stranded positive-sense RNA encapsulated within a membrane envelop with an average diameter of 75-150 nm [114]. The SARS-CoV-2 spike (S) surface glycoprotein is a large highly antigenic type I transmembrane protein with the ability to induce the humoral and cellular immune responses $[115,116]$. Vaccines for SARS-CoV-2 include live attenuated vaccines, inactivated vaccines, recombinant protein vaccines, vector vaccines, deoxyribonucleic acid (DNA) vaccines and messenger ribonucleic acid (mRNA) vaccines (Table 2) [117-127].

According to the Danish National Patient Registry, the reported incidence rate of thromboembolic events among vaccinated Europeans is not increased relative to the expected number estimated from incidence rates from the entire Danish population [128]. However, this Danish report could not rule out a causative relationship between vaccines and thrombotic events [129]. Thirty-nine cases of vaccine-induced immune thrombotic thrombocytopenia (VITT), a syndrome characterized by thrombosis and thrombocytopenia that developed soon after vaccination with the chimpanzee adenovirus ChAdOx1 nCoV-19 
vector (AstraZeneca), have been described [130-132]. Patients were more frequently young ( $<50$ years) females and events mainly occurred at atypical sites (cerebral venous sinus or portal/splanchnic/hepatic veins thromboses) accompanied by low platelet count and high levels of antibodies to platelet factor 4 (PF4)-polyanion complexes despite the absence of heparin [132]. Successively 12 cases of cerebral venous sinus thrombosis meeting the clinical features of VITT have been reported after vaccination with the human adenovirus Ad26 vector (Janssen/Johnson \& Johnson) [133]. Patients' ages ranged from 18 to younger than 60 years; all were white women. So far only one case of possible VITT has been reported after the second dose of a mRNA vaccine (Moderna) in a 65 y.o. man with multiple vein thromboses, including cerebral veins and thrombocytopenia [134]. However, the number of Moderna COVID-19 vaccine doses administered in the United States as of 22 July 2021 was 137 million (source: Centers for Disease Control and Prevention) and the risk of VITT should be considered associated only to viral vector-based vaccines. More than one hundred cases of VITT syndrome have been described in detail [135]. The incidence of VITT syndrome estimated by the reports of the UK, Europe and US Regulatory Agencies is 1.3 per 100,000 first doses and 1.3 per million second doses of the Astrazeneca vaccine; the incidence of AD26.CoV2.S vaccine (Janssen/Johnson \& Johnson, manufactured by Janssen Biotech, Inc., a Janssen Pharmaceutical Company of Johnson \& Johnson, Horsham, PA 19044, USA) is 3.2 per million doses [136]. Due to the very low prevalence of VITT, the overall benefits of the vaccine in preventing COVID-19 outweigh the risks of side effects $[137,138]$.

COVID-19 elicits an impaired antibody response against SARS-CoV-2 in patients with hematological malignancies [139]. Hence, patients with hematological neoplasia are likely to have lower responses to vaccines due to reduced immunological competence that is related to both the hematological disease and the immunosuppressive and/or myelotoxic effects of the treatments [140]. Particularly, patients with MPNs suffer from distinct immune deficiencies and receive different treatments that variously affect the vaccine response [141,142]. In a cohort of $30 \mathrm{MPN}$ patients at 5 weeks from the administration of the BNT162b2 (Pfizer-BioNTech, manufactured by Pfizer Inc., New York, NY 10017, USA, for BioNTech Manufacturing GmbH, 55131 Mainz, Germany) vaccine, seroconversion at cutoff of $15 \mathrm{AU} / \mathrm{mL}$ Ig was reported in $88 \%$ [143]. Very recently, a memory T cell response was observed in $16(80 \%)$ MPN patients having received a first dose of the BNT162b2 (Pfizer-BioNTech) vaccine. After 21 days, a CD4+ T cell response was observed in 15 (75\%) individuals and a CD8+ T cell response was observed in seven (35\%). A polyfunctional T cell response was also observed in $13(65 \%)$ of the patients. The administration of specific therapy was not associated with significant differences in $\mathrm{T}$ cell or antibody responses compared to active surveillance. In addition, no significant differences were observed between patients taking ruxolitinib and those receiving other therapies [144]. On the opposite, seroconversion post-COVID-19 vaccines has been reported to be negatively affected in patients receiving ruxolitinib [145-147]. 
Table 2. Main features of COVID-19 vaccines.

\begin{tabular}{|c|c|c|c|c|c|c|c|c|c|c|}
\hline Developer & Platform & Mechanism & Advantages & Limitations & Doses & Efficacy & $\begin{array}{l}\text { No. of } \\
\text { Subjects }\end{array}$ & $\begin{array}{c}\text { Local Adverse } \\
\text { Events (Pain, } \\
\text { Erythema, Swelling } \\
\text { in the } \\
\text { Injection Side) }\end{array}$ & $\begin{array}{l}\text { Systemic Adverse } \\
\text { Events (Fever, } \\
\text { Headache, Fatigue, } \\
\text { Myalgia, Arthralgia) }\end{array}$ & $\begin{array}{l}\text { Severe Adverse } \\
\text { Events }\end{array}$ \\
\hline $\begin{array}{c}\text { Pfizer/BioNTech } \\
\text { [119] }\end{array}$ & mRNA & $\begin{array}{l}\text { mRNA encoding } \\
\text { for target viral } \\
\text { proteins }\end{array}$ & $\begin{array}{l}\text { No interactions } \\
\text { with the } \\
\text { recipient's DNA }\end{array}$ & $\begin{array}{l}\text { To be stored at } \\
\text { very low } \\
\text { temperatures }\end{array}$ & $\begin{array}{l}2 \text { (3 weeks } \\
\text { apart) }\end{array}$ & $95.0 \%$ & 43,448 & $\begin{array}{c}<55 \mathrm{y}: 83 \% / 88 \% \\
\text { (1st/2nd injection) } \\
>55 \mathrm{y}: 71 \% / 66 \% \\
\text { (1st/2nd injection) }\end{array}$ & $\begin{array}{c}<55 \mathrm{y}: 47 \% / 59 \% \\
\text { (1st/2nd injection) } \\
>55 \mathrm{y}: 34 \% / 51 \% \\
\text { (1st/2nd injection) }\end{array}$ & $0.6 \%$ \\
\hline Moderna [118] & mRNA & $\begin{array}{l}\text { mRNA encoding } \\
\text { for target viral } \\
\text { proteins }\end{array}$ & $\begin{array}{l}\text { No interactions } \\
\text { with the } \\
\text { recipient's DNA }\end{array}$ & $\begin{array}{l}\text { To be stored at } \\
\text { very low } \\
\text { temperatures }\end{array}$ & $\begin{array}{l}2 \text { (4 weeks } \\
\text { apart) }\end{array}$ & $94.1 \%$ & 30,420 & $\begin{array}{c}84.2 \% / 88.6 \% \\
\text { (1st/2nd injection) }\end{array}$ & $\begin{array}{l}54.9 \% \text { (1st injection) } \\
\text { and } 79.4 \% \text { (2nd } \\
\text { injection) }\end{array}$ & $0.5 \%$ \\
\hline $\begin{array}{c}\text { Janssen/Johnson } \\
\text { \& Johnson [124] }\end{array}$ & $\begin{array}{l}\text { DNA } \\
\text { Adenovirus } \\
\text { vector }\end{array}$ & $\begin{array}{l}\text { Plasmid DNA that } \\
\text { contains } \\
\text { mammalian } \\
\text { expression } \\
\text { promotors and the } \\
\text { target gene }\end{array}$ & Highly stable & $\begin{array}{l}\text { Low immuno- } \\
\text { genicity }\end{array}$ & 1 & $67.0 \%$ & 805 & $\begin{array}{l}<55 y: 64 \% / 78 \% \\
\text { (low/high-dose) } \\
>55 y: 41 \% / 42 \% \\
\text { (low } / \text { high-dose) }\end{array}$ & $\begin{array}{l}<55 y: 65 \% / 84 \% \\
\text { (low/high-dose) } \\
>55 y: 46 \% / 55 \% \\
\text { (low/high-dose) }\end{array}$ & $\begin{array}{l}1 \% / 7 \% \\
\text { (low } / \text { high- } \\
\text { dose) }\end{array}$ \\
\hline $\begin{array}{c}\text { AstraZeneca/ } \\
\text { University of } \\
\text { Oxford/Serum } \\
\text { Institute of India } \\
\text { [126] }\end{array}$ & $\begin{array}{l}\text { DNA Aden- } \\
\text { ovirusvector }\end{array}$ & $\begin{array}{l}\text { Plasmid DNA that } \\
\text { contains } \\
\text { mammalian } \\
\text { expression } \\
\text { promotors and the } \\
\text { target gene }\end{array}$ & Highly stable & $\begin{array}{l}\text { Low immuno- } \\
\text { genicity }\end{array}$ & $\begin{array}{l}2(4 / 8 \text { to } \\
12 \text { weeks } \\
\text { apart) }\end{array}$ & $70.4 \%$ & 11,636 & n.r. & n.r. & $\begin{array}{l}175 \text { adverse } \\
\text { events ( } 84 \text { in the } \\
\text { Vaxzeria group) }\end{array}$ \\
\hline Novavax [148] & $\begin{array}{l}\text { Recombinant } \\
\text { protein }\end{array}$ & $\begin{array}{l}\text { Viral proteins that } \\
\text { have been } \\
\text { expressed in one } \\
\text { of various systems }\end{array}$ & $\begin{array}{l}\text { Safe; no live } \\
\text { components } \\
\text { ofthe virus }\end{array}$ & $\begin{array}{l}\text { Memory is to } \\
\text { be tested }\end{array}$ & $\begin{array}{l}2 \text { (3 weeks } \\
\text { apart) }\end{array}$ & $89.0 \%$ & 131 & about $85 \%$ & about $79 \%$ & $\begin{array}{c}1 \text { severe local } \\
\text { event } \\
8 \text { severe } \\
\text { systemic events }\end{array}$ \\
\hline $\begin{array}{c}\text { Gamaleya } \\
\text { Institute [149] }\end{array}$ & $\begin{array}{l}\text { DNA } \\
\text { Adenovirus } \\
\text { vectors }\end{array}$ & $\begin{array}{l}\text { Plasmid DNA that } \\
\text { contains } \\
\text { mammalian } \\
\text { expression } \\
\text { promotors and the } \\
\text { target gene }\end{array}$ & Highly stable & $\begin{array}{l}\text { Low immuno- } \\
\text { genicity }\end{array}$ & $\begin{array}{l}2 \text { (3 weeks } \\
\text { apart) }\end{array}$ & $91.6 \%$ & 21,977 & $5.4 \%$ & $15.2 \%$ & $0.3 \%$ \\
\hline
\end{tabular}


In a small cohort of MPN patients, those receiving treatment with peg.interferon had the highest serological response in comparison with ruxolitinib or hydroxyurea. Notably, only two-thirds of the patients not receiving cytoreduction seroconverted [150].

All patients with MPN must receive vaccination against COVID-19. No specific MPNrelated risks associated with vaccination are known. There are reassuring data concerning efficacy of COVID-19 mRNA vaccine in the general MPN population; however, the use of ruxolitinib could impair the seroconversion after vaccination.

\section{What Is the Value of Telemedicine in Patients with MPNs during the SARS-CoV-2 Pandemic?}

Telemedicine is the use of telecommunications technology as a tool to deliver health care [151-155].

The COVID-19 pandemic further highlighted how health care facilities can spread the virus and focused attention on new models of care that reduce in-person contacts to lessen the transmission of the virus and protect medical practitioners from infection [156-160]. Accordingly, the indication to move outpatient clinics to telephone or video-conferencing appointments was suggested in all patients with cancer, including MPNs [57,161,162].

During the first pandemic wave, the Italian GIMEMA Working Group on MPNs launched a survey that was responded by 98 Italian Hematologists with specific focus on clinical management of MPNs during the pandemic. Over 80\% medical visits were converted into telehealth in $19.8 \%, 38 \%$ and $50 \%$ of MF, PV and ET patients, respectively [79]. In addition, hematologists declared a certain propensity to expand the use of telemedicine after pandemic resolution [79].

A recent analysis concerning the use of telemedicine at the Institute of Hematology "L. and A. Seràgnoli", Bologna, Italy, showed that during the first pandemic wave (9 March-4 May 2020) a total of 365 out of 489 (74.6\%) visits were converted to telephone appointments. Compared to patients receiving a telephone contact, the patients who required in-person visits were more frequently affected by MF $(p<0.001)$, were under active therapy $(p=0.03)$ and enrolled into a clinical trial $(p<0.001)$ [163]. Overall, $87(23.8 \%)$ out of 365 patients who were involved in the telemedicine project also responded to a satisfaction questionnaire that analyzed 1. adequacy of medical care; 2 . psychological impact of telemedicine; 3 . adequacy of IT system; 4 . possible advantages and future use of telemedicine. Telemedicine resulted in an overall good level of patients' satisfaction [163]. However, all patients complained due to the lack of physical interaction, which may result in reduced diagnostic accuracy, worse symptom control, impaired evaluation of clinical signs (i.e., splenomegaly), delayed recognition and worse management of MPN-related complications. In addition, the protection of medical-legal aspects, the obtainment of patient's consent and the gratification of the doctor-patient relationship may represent crucial concerns when telemedicine is used [155].

Whether and to what extent telemedicine affected patient outcome in terms of blood count control, symptom control and complications, remains to be clarified.

During the COVID-19 pandemic, the integration of telemedicine and virtual care into the healthcare system emerged as an approach to maximize the efficiency of healthcare delivery by promoting social distancing, reducing face-to-face contacts and virus transmission and avoiding cancelling or postpone outpatient medical visits.

However, telemedicine seems to be more feasible and promising in ET and PV patients with stable disease who are not enrolled into investigational trials. In addition, the presence of a dedicated medical team that can guarantee a high quality of medical care and the cooperation of patients and caregivers may significantly improve the quality of telemedicine. Future studies are required to assess whether telemedicine may negatively affect disease control and MPN-related complications. 


\section{Conclusions}

The COVID-19 pandemic induced a rapid reorganization of healthcare facilities and greatly influenced the management of patients with cancer, who had to face a reduced possibility to perform laboratory tests and hospital visits; some specific therapies have been interrupted or postponed. MPNs and particularly MF patients may be at increased risk of severe SARS-CoV-2 infection. Differently, ET patients are at higher risk of thrombosis. There is uncertainty in the definition of the specific infectious risk related to their disease and to their chronic treatments. In addition, management of thrombotic and hemorrhagic risk may be challenging. The clinical evidence collected to date provides guidance for a proper management of MPN patients during the pandemic (summarized in Table 3). MPN patients should be encouraged to receive vaccination against COVID-19; the use of mRNA-based vaccines has proved safe and effective. The vaccine efficacy in patients with MPN, compared to the different specific therapies and the potential specific risks associated to the different vaccines, remain to be defined.

Overall, the experience gained in this pandemic year has also represented an opportunity for improvement in some areas, including the development of telemedicine, the expansion of international cooperation and the acceleration of approval pathways and implementation of clinical trials. 
Table 3. Suggested strategies in the management of chronic myeloproliferative neoplasms under COVID-19 pandemic.

\begin{tabular}{|c|c|c|c|c|}
\hline Disease & Diagnostic Procedures & Initial Therapy & Intolerant/Resistant Patients & Confirmed COVID-19 \\
\hline Polycythemia Vera & $\begin{array}{c}\text { All patients should receive a } \\
\text { 2016WHO-defined diagnosis. } \\
\text { A delay of BM biopsy may be considered if } \\
\text { clinical/laboratory parameters are diagnostic } \\
\text { for PV }\end{array}$ & $\begin{array}{l}\text { Anti COVID-19 vaccination is indicated } \\
\text { Patients do not need be tested for COVID-19 } \\
\text { prior to initiation of therapy. } \\
\text { Antiplatelet agents according to standard } \\
\text { indications. } \\
\text { If newly diagnosed indication for oral } \\
\text { anticoagulation, DOAC instead of VKA may } \\
\text { be appropriate. } \\
\text { In patients treated with phlebotomy only, the } \\
\text { hematocrit threshold should be kept } \\
<45 \% \text { Cytoreduction should be started in all } \\
\text { patients at high thrombotic risk. } \\
\text { The cytoreductive agent should be chosen on } \\
\text { a case-by-case evaluation }\end{array}$ & $\begin{array}{l}\text { There is no contraindication of switching to a } \\
\text { second line cytoreductive agent in case of } \\
\text { intolerance or resistance. } \\
\text { The start of ruxolitinib should not be delayed }\end{array}$ & $\begin{array}{c}\text { For non-severe COVID-19 infection, interruption of cytoreductive } \\
\text { agents or ruxolitinib is not recommended. } \\
\text { For severe COVID-19 infection, dose reduction or interruption of } \\
\text { cytoreductive agents should be based on complete blood count } \\
\text { evaluation. } \\
\text { The interruption of ruxolitinib during COVID-19 should be } \\
\text { discouraged, but discussed case by case } \\
\text { Caution should be taken with the drug-drug interactions between } \\
\text { treatment of COVID-19 and ruxolitinib. } \\
\text { Switch to LMWH may be suggested in patients on anticoagulation. } \\
\text { The use of LMWH is recommended in all hospitalized cases, after } \\
\text { evaluation of the hemorrhagic risk } \\
\text { Aspirin should not be discontinued in the patients with a history of } \\
\text { arterial thrombosis }\end{array}$ \\
\hline $\begin{array}{l}\text { Essential } \\
\text { Thrombocythemia }\end{array}$ & $\begin{array}{l}\text { All patients should receive a } \\
2016 \text { WHO-defined diagnosis. } \\
\text { A delay of BM biopsy after the resolution of } \\
\text { the pandemic may be considered if a MPN } \\
\text { driver mutation or another clonal marker is } \\
\text { present and clinical/laboratory parameters } \\
\text { are in line with ET }\end{array}$ & $\begin{array}{l}\text { Anti COVID-19 vaccination is indicated } \\
\text { COVID-19 swab/serology is not required but } \\
\text { it may be suggested prior to initiation of } \\
\text { therapy } \\
\text { Antiplatelet agents according to standard } \\
\text { indications } \\
\text { If newly diagnosed indication for oral } \\
\text { anticoagulation, DOAC instead of VKA may } \\
\text { be appropriate. } \\
\text { Cytoreduction should be started in all } \\
\text { patients at high thrombotic risk. } \\
\text { The cytoreductive agent should be chosen on } \\
\text { a case-by-case evaluation }\end{array}$ & $\begin{array}{l}\text { There is no contraindication of switching to a } \\
\text { second line cytoreductive agent in case of } \\
\text { intolerance or resistance }\end{array}$ & $\begin{array}{l}\text { For non-severe COVID-19, interruption of cytoreductive agents is not } \\
\text { recommended. } \\
\text { For severe COVID-19, dose reduction or interruption of cytoreductive } \\
\text { agents should be based on complete blood count evaluation. } \\
\text { Switch to LMWH may be suggested in patients on anticoagulation } \\
\text { The use of LMWH is recommended in all hospitalized cases, after } \\
\text { evaluation of the hemorrhagic risk } \\
\text { Aspirin should not be discontinued in the patients with a history of } \\
\text { arterial thrombosis }\end{array}$ \\
\hline Myelofibrosis & $\begin{array}{l}\text { All patients should receive a } 2016 \\
\text { WHO-defined diagnosisA delay of BM biopsy } \\
\text { after the resolution of the pandemic should be } \\
\text { discouraged }\end{array}$ & $\begin{array}{l}\text { Anti COVID-19 vaccination is indicated } \\
\text { Patients do not need be tested for COVID-19 } \\
\text { prior to initiation of therapy. } \\
\text { The initiation of ruxolitinib should not be } \\
\text { delayed if clinically needed } \\
\text { Hydroxyurea can be started according to } \\
\text { clinical need } \\
\text { Initiation of anti-anemia therapy should be } \\
\text { started to reduce the need of } \\
\text { RBC transfusions }\end{array}$ & $\begin{array}{l}\text { There is no contraindication of switching to } \\
\text { cytoreductive agents/fedratinib } \\
\text { Splenectomy should not be delayed if } \\
\text { indicated since there are no data indicating an } \\
\text { increased risk of COVID-19 } \\
\text { infection/complication. The delay could } \\
\text { exacerbate abdominal symptoms and delay } \\
\text { ASCT. Pre-splenectomy vaccine prophylaxis } \\
\text { is recommended. } \\
\text { The indication and timing of ASCT are based } \\
\text { on disease status. }\end{array}$ & $\begin{array}{c}\text { The interruption of ruxolitinib during COVID-19 infection should be } \\
\text { discouraged but discussed case by case } \\
\text { Caution should be taken with the drug-drug interactions between } \\
\text { treatment of COVID-19 and ruxolitinib } \\
\text { Switch to LMWH may be suggested in patients on anticoagulation. } \\
\text { The use of LMWH is recommended in all hospitalized cases, after } \\
\text { evaluation of the hemorrhagic risk } \\
\text { Aspirin should not be discontinued in the patients with a history of } \\
\text { arterial thrombosis } \\
\text { In patients with MF and thrombocytopenia MF-related, special } \\
\text { attention should be paid to the risk/benefit balance associated with } \\
\text { the antithrombotic prophylaxis }\end{array}$ \\
\hline
\end{tabular}

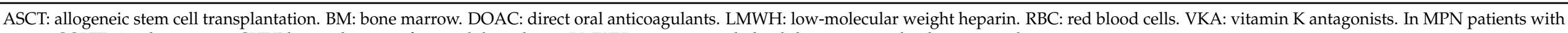
severe COVID-19, that present CVRF but no history of arterial thrombosis, LMWH is recommended, while aspirin can be discontinued. 
Author Contributions: Conceptualization, F.P. (Francesca Palandri); methodology, F. P. (Francesca Palandri), V.D.S.; software, NA.; validation, all authors.; formal analysis, NA.; investigation, all authors.; resources, all authors; data curation, NA.; writing — original draft preparation, all authors; writing-review and editing, F.P. (Francesca Palandri), V.D.S.; visualization, F.P. (Francesca Palandri), V.D.S.; supervision, F.P. (Francesca Palandri), V.D.S.; project administration, F.P. (Francesca Palandri); funding acquisition, F.P. (Francesco Passamonti). All authors have read and agreed to the published version of the manuscript.

Funding: This research was funded by the Ministero della Salute, Rome, Italy [Finalizzata 2018, NET-2018-12365935, Personalized medicine program on myeloid neoplasms: characterization of the patient's genome for clinical decision making and systematic collection of real world data to improve quality of health care], and by the Ministero dell'Istruzione, dell'Università e della Ricerca, Roma, Italy [PRIN 2017, 2017WXR7ZT; Myeloid Neoplasms: an integrated clinical, molecular and therapeutic approach]. No funding was received for the APC.

Acknowledgments: This work was supported by Associazione Italiana contro Leucemie, Linfomi e Mieloma (AIL), Bologna. We thank Daniela Bartoletti for her valuable assistance in the preparation and submission of the manuscript. FPas was supported by grants from the Ministero della Salute, Rome, Italy [Finalizzata 2018, NET-2018-12365935, Personalized medicine program on myeloid neoplasms: characterization of the patient's genome for clinical decision making and systematic collection of real world data to improve quality of health care], by grants from the Ministero dell'Istruzione, dell'Università e della Ricerca, Roma, Italy [PRIN 2017, 2017WXR7ZT; Myeloid Neoplasms: an integrated clinical, molecular and therapeutic approach] and by Fondazione Matarelli, Milan.

Conflicts of Interest: The authors declare no competing interests.

\section{References}

1. de Wilde, A.H.; Snijder, E.J.; Kikkert, M.; van Hemert, M.J. Host Factors in Coronavirus Replication. Curr. Top. Microbiol. Immunol. 2018, 419, 1-42. [CrossRef] [PubMed]

2. Vijaykrishna, D.; Smith, G.J.; Zhang, J.X.; Peiris, J.S.; Chen, H.; Guan, Y. Evolutionary insights into the ecology of coronaviruses. J. Virol. 2007, 81, 4012-4020. [CrossRef] [PubMed]

3. de Wit, E.; van Doremalen, N.; Falzarano, D.; Munster, V.J. SARS and MERS: Recent insights into emerging coronaviruses. Nature reviews. Microbiology 2016, 14, 523-534. [CrossRef] [PubMed]

4. Paules, C.I.; Marston, H.D.; Fauci, A.S. Coronavirus Infections-More Than Just the Common Cold. JAMA 2020, 323, 707-708. [CrossRef]

5. Zhu, N.; Zhang, D.; Wang, W.; Li, X.; Yang, B.; Song, J.; Zhao, X.; Huang, B.; Shi, W.; Lu, R.; et al. A Novel Coronavirus from Patients with Pneumonia in China, 2019. N. Engl. J. Med. 2020, 382, 727-733. [CrossRef]

6. Xu, X.; Chen, P.; Wang, J.; Feng, J.; Zhou, H.; Li, X.; Zhong, W.; Hao, P. Evolution of the novel coronavirus from the ongoing Wuhan outbreak and modeling of its spike protein for risk of human transmission. Sci. China Life Sci. 2020, 63, 457-460. [CrossRef]

7. Guan, W.J.; Ni, Z.Y.; Hu, Y.; Liang, W.H.; Ou, C.Q.; He, J.X.; Liu, L.; Shan, H.; Lei, C.L.; Hui, D.S.C.; et al. Clinical Characteristics of Coronavirus Disease 2019 in China. N. Engl. J. Med. 2020, 382, 1708-1720. [CrossRef] [PubMed]

8. Thachil, J.; Cushman, M.; Srivastava, A. A proposal for staging COVID-19 coagulopathy. Res. Pract. Thromb. Haemost. 2020, 4 , 731-736. [CrossRef]

9. Bedford, J.; Enria, D.; Giesecke, J.; Heymann, D.L.; Ihekweazu, C.; Kobinger, G.; Lane, H.C.; Memish, Z.; Oh, M.D.; Sall, A.A.; et al. COVID-19: Towards controlling of a pandemic. Lancet 2020, 395, 1015-1018. [CrossRef]

10. Johns Hopkins University. COVID-19 Dashboard by the Center for Systems Science and Engineering (CSSE) at Johns Hopkins University (JHU). 2020. Available online: https://gisanddata.maps.arcgis.com/apps/opsdashboard/index.html\#/bda7594740 fd40299423467b40299423448e40299423469ecf40299423466 (accessed on 18 May 2021).

11. Liang, W.; Guan, W.; Chen, R.; Wang, W.; Li, J.; Xu, K.; Li, C.; Ai, Q.; Lu, W.; Liang, H.; et al. Cancer patients in SARS-CoV-2 infection: A nationwide analysis in China. The Lancet. Oncology 2020, 21, 335-337. [CrossRef]

12. Xia, Y.; Jin, R.; Zhao, J.; Li, W.; Shen, H. Risk of COVID-19 for patients with cancer. Lancet Oncol. 2020, 21, e180. [CrossRef]

13. Wang, H.; Zhang, L. Risk of COVID-19 for patients with cancer. Lancet Oncol. 2020, 21, e181. [CrossRef]

14. Giri, M.; Puri, A.; Wang, T.; Guo, S. Comparison of clinical manifestations, pre-existing comorbidities, complications and treatment modalities in severe and non-severe COVID-19 patients: A systemic review and meta-analysis. Sci. Prog. 2021, 104, 1-24. [CrossRef] [PubMed]

15. Arber, D.A.; Orazi, A.; Hasserjian, R.; Thiele, J.; Borowitz, M.J.; Le Beau, M.M.; Bloomfield, C.D.; Cazzola, M.; Vardiman, J.W. The 2016 revision to the World Health Organization classification of myeloid neoplasms and acute leukemia. Blood 2016, 127, 2391-2405. [CrossRef] 
16. Barbui, T.; Tefferi, A.; Vannucchi, A.M.; Passamonti, F.; Silver, R.T.; Hoffman, R.; Verstovsek, S.; Mesa, R.; Kiladjian, J.J.; Hehlmann, R.; et al. Philadelphia chromosome-negative classical myeloproliferative neoplasms: Revised management recommendations from European LeukemiaNet. Leukemia 2018, 32, 1057-1069. [CrossRef]

17. Polverelli, N.; Breccia, M.; Benevolo, G.; Martino, B.; Tieghi, A.; Latagliata, R.; Sabattini, E.; Riminucci, M.; Godio, L.; Catani, L.; et al. Risk factors for infections in myelofibrosis: Role of disease status and treatment. A multicenter study of 507 patients. Am. J. Hematol. 2017, 92, 37-41. [CrossRef] [PubMed]

18. Hultcrantz, M.; Wilkes, S.R.; Kristinsson, S.Y.; Andersson, T.M.; Derolf Å, R.; Eloranta, S.; Samuelsson, J.; Landgren, O.; Dickman, P.W.; Lambert, P.C.; et al. Risk and Cause of Death in Patients Diagnosed with Myeloproliferative Neoplasms in Sweden Between 1973 and 2005: A Population-Based Study. J. Clin. Oncol. Off. J. Am. Soc. Clin. Oncol. 2015, 33, 2288-2295. [CrossRef]

19. Froom, P.; Aghai, E.; Kinarty, A.; Lahat, N. Decreased natural killer (NK) activity in patients with myeloproliferative disorders. Cancer 1989, 64, 1038-1040. [CrossRef]

20. Cervantes, F.; Hernández-Boluda, J.C.; Villamor, N.; Serra, A.; Montserrat, E. Assessment of peripheral blood lymphocyte subsets in idiopathic myelofibrosis. Eur. J. Haematol. 2000, 65, 104-108. [CrossRef]

21. Briard, D.; Brouty-Boyé, D.; Giron-Michel, J.; Azzarone, B.; Jasmin, C.; Le Bousse-Kerdilès, C. Impaired NK cell differentiation of blood-derived CD34+ progenitors from patients with myeloid metaplasia with myelofibrosis. Clin. Immunol. 2003, 106, $201-212$. [CrossRef]

22. Barosi, G. An immune dysregulation in MPN. Curr. Hematol. Malig. Rep. 2014, 9, 331-339. [CrossRef] [PubMed]

23. Wang, J.C.; Sindhu, H.; Chen, C.; Kundra, A.; Kafeel, M.I.; Wong, C.; Lichter, S. Immune derangements in patients with myelofibrosis: The role of Treg, Th17, and sIL2R $\alpha$. PLoS ONE 2015, 10, e0116723. [CrossRef]

24. Wang, J.C.; Kundra, A.; Andrei, M.; Baptiste, S.; Chen, C.; Wong, C.; Sindhu, H. Myeloid-derived suppressor cells in patients with myeloproliferative neoplasm. Leuk. Res. 2016, 43, 39-43. [CrossRef]

25. Landtblom, A.R.; Andersson, T.M.; Dickman, P.W.; Smedby, K.E.; Eloranta, S.; Batyrbekova, N.; Samuelsson, J.; Björkholm, M.; Hultcrantz, M. Risk of infections in patients with myeloproliferative neoplasms-a population-based cohort study of 8363 patients. Leukemia 2021, 35, 476-484. [CrossRef]

26. Lussana, F.; Cattaneo, M.; Rambaldi, A.; Squizzato, A. Ruxolitinib-associated infections: A systematic review and meta-analysis. Am. J. Hematol. 2018, 93, 339-347. [CrossRef]

27. Parampalli Yajnanarayana, S.; Stübig, T.; Cornez, I.; Alchalby, H.; Schönberg, K.; Rudolph, J.; Triviai, I.; Wolschke, C.; Heine, A.; Brossart, P.; et al. JAK1/2 inhibition impairs T cell function in vitro and in patients with myeloproliferative neoplasms. Br. J. Haematol. 2015, 169, 824-833. [CrossRef] [PubMed]

28. Schönberg, K.; Rudolph, J.; Vonnahme, M.; Parampalli Yajnanarayana, S.; Cornez, I.; Hejazi, M.; Manser, A.R.; Uhrberg, M.; Verbeek, W.; Koschmieder, S.; et al. JAK Inhibition Impairs NK Cell Function in Myeloproliferative Neoplasms. Cancer Res. 2015, 75, 2187-2199. [CrossRef]

29. Keohane, C.; Kordasti, S.; Seidl, T.; Perez Abellan, P.; Thomas, N.S.; Harrison, C.N.; McLornan, D.P.; Mufti, G.J. JAK inhibition induces silencing of T Helper cytokine secretion and a profound reduction in T regulatory cells. Br. J. Haematol. 2015, 171, 60-73. [CrossRef]

30. Rudolph, J.; Heine, A.; Quast, T.; Kolanus, W.; Trebicka, J.; Brossart, P.; Wolf, D. The JAK inhibitor ruxolitinib impairs dendritic cell migration via off-target inhibition of ROCK. Leukemia 2016, 30, 2119-2123. [CrossRef]

31. Massa, M.; Rosti, V.; Campanelli, R.; Fois, G.; Barosi, G. Rapid and long-lasting decrease of T-regulatory cells in patients with myelofibrosis treated with ruxolitinib. Leukemia 2014, 28, 449-451. [CrossRef]

32. Schönberg, K.; Rudolph, J.; Yajnanarayana, S.P.; Wolf, D. Get a grip on immune cells by inhibiting JAKs. Oncoimmunology 2016, 5, e1071009. [CrossRef] [PubMed]

33. Barone, M.; Catani, L.; Ricci, F.; Romano, M.; Forte, D.; Auteri, G.; Bartoletti, D.; Ottaviani, E.; Tazzari, P.L.; Vianelli, N.; et al. The role of circulating monocytes and JAK inhibition in the infectious-driven inflammatory response of myelofibrosis. Oncoimmunology 2020, 9, 1782575. [CrossRef] [PubMed]

34. Chen, C.X.; Wang, J.J.; Li, H.; Yuan, L.T.; Gale, R.P.; Liang, Y. JAK-inhibitors for coronavirus disease-2019 (COVID-19): A meta-analysis. Leukemia 2021, 1-5. [CrossRef]

35. Crodel, C.C.; Jentsch-Ullrich, K.; Koschmieder, S.; Kämpfe, D.; Griesshammer, M.; Döhner, K.; Jost, P.J.; Wolleschak, D.; Isfort, S.; Stegelmann, F.; et al. Frequency of infections in 948 MPN patients: A prospective multicenter patient-reported pilot study. Leukemia 2020, 34, 1949-1953. [CrossRef]

36. Kricheldorf, K.; Döhner, K.; Stegelmann, F.; Jost, P.J.; Lang, F.; Radsak, M.; Hansen, R.; Heuer, V.; Röhrig, R.; Brümmendorf, T.H.; et al. Challenges of patients with myeloproliferative neoplasms (MPN) in times of COVID: First results from a patient survey by the German Study Group for MPN. Leuk. Res. 2021, 110, 106646. [CrossRef]

37. Simpson-Poirier, K.; Harnois, M.; Olney, H.J.; Sirhan, S.; Gratton, M.O.; Assouline, S.; Laneuville, P.; Delage, R.; Mollica, L.; Busque, L.; et al. Risk of infection in MPN patients in the era of Covid-19: A prospective multicenter study of 257 patients from the CML-MPN Quebec Research Group. Am. J. Hematol. 2021, 96, E200-E203. [CrossRef]

38. Saunders, J.; Curto-Garcia, N.; Sriskandarajah, P.; O'Sullivan, J.; Woodley, C.; Asirvatham, S.; Campbell-Drew, M.; Mathias, J.; Ellis, T.; Baker, N.; et al. Large Scale Internet-based Survey of Patients With a Myeloproliferative Neoplasm: Opinions and Experiences Regarding SARS-CoV-2 (COVID-19) Vaccination Strategies in 2021. HemaSphere 2021, 5, e609. [CrossRef] [PubMed] 
39. Breccia, M.; Piciocchi, A.; De Stefano, V.; Finazzi, G.; Iurlo, A.; Fazi, P.; Soddu, S.; Martino, B.; Palandri, F.; Siragusa, S.; et al. COVID-19 in Philadelphia-negative myeloproliferative disorders: A GIMEMA survey. Leukemia 2020, 34, 2813-2814. [CrossRef]

40. Ash Research Collaborative. COVID-19 Registry. 2021. Available online: https://www.ashresearchcollaborative.org/s/ covid-19-registry (accessed on 26 May 2021).

41. Wang, Q.; Berger, N.A.; Xu, R. When hematologic malignancies meet COVID-19 in the United States: Infections, death and disparities. Blood Rev. 2021, 47, 100775. [CrossRef]

42. Passamonti, F.; Cattaneo, C.; Arcaini, L.; Bruna, R.; Cavo, M.; Merli, F.; Angelucci, E.; Krampera, M.; Cairoli, R.; Della Porta, M.G.; et al. Clinical characteristics and risk factors associated with COVID-19 severity in patients with haematological malignancies in Italy: A retrospective, multicentre, cohort study. Lancet Haematol. 2020, 7, e737-e745. [CrossRef]

43. García-Suárez, J.; de la Cruz, J.; Cedillo, Á.; Llamas, P.; Duarte, R.; Jiménez-Yuste, V.; Hernández-Rivas, J.; Gil-Manso, R.; Kwon, M.; Sánchez-Godoy, P.; et al. Impact of hematologic malignancy and type of cancer therapy on COVID-19 severity and mortality: Lessons from a large population-based registry study. J. Hematol. Oncol. 2020, 13, 133. [CrossRef] [PubMed]

44. Salisbury, R.A.; Curto-Garcia, N.; O’Sullivan, J.; Chen, F.; Polzella, P.; Godfrey, A.L.; Russell, J.; Knapper, S.; Willan, J.; Frewin, R.; et al. Results of a national UK physician reported survey of COVID-19 infection in patients with a myeloproliferative neoplasm. Leukemia 2021, 35, 2424-2430. [CrossRef] [PubMed]

45. Barbui, T.; Vannucchi, A.M.; Alvarez-Larran, A.; Iurlo, A.; Masciulli, A.; Carobbio, A.; Ghirardi, A.; Ferrari, A.; Rossi, G.; Elli, E.; et al. High mortality rate in COVID-19 patients with myeloproliferative neoplasms after abrupt withdrawal of ruxolitinib. Leukemia 2021, 35, 485-493. [CrossRef]

46. El-Sharkawi, D.; Iyengar, S. Haematological cancers and the risk of severe COVID-19: Exploration and critical evaluation of the evidence to date. Br. J. Haematol. 2020, 190, 336-345. [CrossRef] [PubMed]

47. Barbui, T.; Iurlo, A.; Masciulli, A.; Carobbio, A.; Ghirardi, A.; Rossi, G.; Harrison, C.; Alvarez-Larran, A.; Elli, E.M.; Kiladjian, J.J.; et al. Long-term follow-up of recovered MPN patients with COVID-19. Blood Cancer J. 2021, 11, 115. [CrossRef]

48. Barbui, T.; De Stefano, V.; Carobbio, A.; Iurlo, A.; Alvarez-Larran, A.; Cuevas, B.; Ferrer Marín, F.; Vannucchi, A.M.; Palandri, F.; Harrison, C.; et al. Direct oral anticoagulants for myeloproliferative neoplasms: Results from an international study on 442 patients. Leukemia 2021, 1-5. [CrossRef]

49. De Stefano, V.; Ruggeri, M.; Cervantes, F.; Alvarez-Larrán, A.; Iurlo, A.; Randi, M.L.; Elli, E.; Finazzi, M.C.; Finazzi, G.; Zetterberg, E.; et al. High rate of recurrent venous thromboembolism in patients with myeloproliferative neoplasms and effect of prophylaxis with vitamin K antagonists. Leukemia 2016, 30, 2032-2038. [CrossRef]

50. Leentjens, J.; van Haaps, T.F.; Wessels, P.F.; Schutgens, R.E.G.; Middeldorp, S. COVID-19-associated coagulopathy and antithrombotic agents-lessons after 1 year. Lancet Haematol. 2021, 8, e524-e533. [CrossRef]

51. Connors, J.M.; Levy, J.H. COVID-19 and its implications for thrombosis and anticoagulation. Blood 2020, 135, 2033-2040. [CrossRef]

52. Al-Samkari, H.; Karp Leaf, R.S.; Dzik, W.H.; Carlson, J.C.T.; Fogerty, A.E.; Waheed, A.; Goodarzi, K.; Bendapudi, P.K.; Bornikova, L.; Gupta, S.; et al. COVID-19 and coagulation: Bleeding and thrombotic manifestations of SARS-CoV-2 infection. Blood 2020, 136, 489-500. [CrossRef]

53. Barbui, T.; De Stefano, V.; Alvarez-Larran, A.; Iurlo, A.; Masciulli, A.; Carobbio, A.; Ghirardi, A.; Ferrari, A.; Cancelli, V.; Elli, E.M.; et al. Among classic myeloproliferative neoplasms, essential thrombocythemia is associated with the greatest risk of venous thromboembolism during COVID-19. Blood Cancer J. 2021, 11, 21. [CrossRef] [PubMed]

54. Barbui, T.; Carobbio, A.; Rumi, E.; Finazzi, G.; Gisslinger, H.; Rodeghiero, F.; Randi, M.L.; Rambaldi, A.; Gisslinger, B.; Pieri, L.; et al. In contemporary patients with polycythemia vera, rates of thrombosis and risk factors delineate a new clinical epidemiology. Blood 2014, 124, 3021-3023. [CrossRef] [PubMed]

55. Barbui, T.; Carobbio, A.; Cervantes, F.; Vannucchi, A.M.; Guglielmelli, P.; Antonioli, E.; Alvarez-Larrán, A.; Rambaldi, A.; Finazzi, G.; Barosi, G. Thrombosis in primary myelofibrosis: Incidence and risk factors. Blood 2010, 115, 778-782. [CrossRef] [PubMed]

56. Carobbio, A.; Thiele, J.; Passamonti, F.; Rumi, E.; Ruggeri, M.; Rodeghiero, F.; Randi, M.L.; Bertozzi, I.; Vannucchi, A.M.; Antonioli, E.; et al. Risk factors for arterial and venous thrombosis in WHO-defined essential thrombocythemia: An international study of 891 patients. Blood 2011, 117, 5857-5859. [CrossRef] [PubMed]

57. Mesa, R.; Alvarez-Larran, A.; Harrison, C.; Kiladjian, J.J.; Rambaldi, A.; Tefferi, A.; Vannucchi, A.; Verstovsek, S.; De Stefano, V.; Barbui, T. COVID-19 Resources, COVID-19 and Myeloproliferative Neoplasms: Frequently Asked Questions. Version 6.0. American Society of Hematology 2021, January 25. Available online: https://www.hematology.org/covid-19/covid-19-andmyeloproliferative-neoplasms (accessed on 18 May 2021).

58. Finazzi, G.; Vannucchi, A.M.; Barbui, T. Prefibrotic myelofibrosis: Treatment algorithm 2018. Blood Cancer J. 2018, 8, 104. [CrossRef] [PubMed]

59. Guglielmelli, P.; Carobbio, A.; Rumi, E.; De Stefano, V.; Mannelli, L.; Mannelli, F.; Rotunno, G.; Coltro, G.; Betti, S.; Cavalloni, C.; et al. Validation of the IPSET score for thrombosis in patients with prefibrotic myelofibrosis. Blood Cancer J. 2020, 10, 21. [CrossRef]

60. Pastori, D.; Mezzaroma, I.; Pignatelli, P.; Violi, F.; Lip, G.Y.H. Atrial fibrillation and human immunodeficiency virus type-1 infection: A systematic review. Implications for anticoagulant and antiarrhythmic therapy. Br. J. Clin. Pharmacol. 2019, 85, 508-515. [CrossRef] 
61. Patti, G.; Lio, V.; Cavallari, I.; Gragnano, F.; Riva, L.; Calabrò, P.; Di Pasquale, G.; Pengo, V.; Rubboli, A. Questions and Answers on Practical Thrombotic Issues in SARS-CoV-2 Infection: A Guidance Document from the Italian Working Group on Atherosclerosis, Thrombosis and Vascular Biology. Am. J. Cardiovasc. Drugs Drugs Devices Interv. 2020, 20, 559-570. [CrossRef]

62. McMullin, M.F.; Harrison, C.N.; Ali, S.; Cargo, C.; Chen, F.; Ewing, J.; Garg, M.; Godfrey, A.; Knapper, S.; McLornan, D.P.; et al. A guideline for the diagnosis and management of polycythaemia vera. A British Society for Haematology Guideline. Br. J. Haematol. 2019, 184, 176-191. [CrossRef]

63. Landolfi, R.; Marchioli, R.; Kutti, J.; Gisslinger, H.; Tognoni, G.; Patrono, C.; Barbui, T. Efficacy and safety of low-dose aspirin in polycythemia vera. N. Engl. J. Med. 2004, 350, 114-124. [CrossRef]

64. Mohammadi, S.; Tabatabaei Yazdi, S.M.; Eshghi, P.; Norooznezhad, A.H. Coronavirus disease 2019 (COVID-19) and decrease in blood donation: Experience of Iranian Blood Transfusion Organization (IBTO). Vox Sang. 2020, 115, 595-596. [CrossRef] [PubMed]

65. Shander, A.; Goobie, S.M.; Warner, M.A.; Aapro, M.; Bisbe, E.; Perez-Calatayud, A.A.; Callum, J.; Cushing, M.M.; Dyer, W.B.; Erhard, J.; et al. Essential Role of Patient Blood Management in a Pandemic: A Call for Action. Anesth. Analg. 2020, 131, 74-85. [CrossRef]

66. Weinkove, R.; McQuilten, Z.K.; Adler, J.; Agar, M.R.; Blyth, E.; Cheng, A.C.; Conyers, R.; Haeusler, G.M.; Hardie, C.; Jackson, C.; et al. Managing haematology and oncology patients during the COVID-19 pandemic: Interim consensus guidance. Med. J. Aust. 2020, 212, 481-489. [CrossRef] [PubMed]

67. Tefferi, A.; Barbui, T. Polycythemia vera and essential thrombocythemia: 2021 update on diagnosis, risk-stratification and management. Am. J. Hematol. 2020, 95, 1599-1613. [CrossRef] [PubMed]

68. Alvarez-Larrán, A.; Cervantes, F.; Pereira, A.; Arellano-Rodrigo, E.; Pérez-Andreu, V.; Hernández-Boluda, J.C.; Ayats, R.; Salvador, C.; Muntañola, A.; Bellosillo, B.; et al. Observation versus antiplatelet therapy as primary prophylaxis for thrombosis in low-risk essential thrombocythemia. Blood 2010, 116, 1205-1210. [CrossRef]

69. Marchioli, R.; Finazzi, G.; Specchia, G.; Cacciola, R.; Cavazzina, R.; Cilloni, D.; De Stefano, V.; Elli, E.; Iurlo, A.; Latagliata, R.; et al Cardiovascular events and intensity of treatment in polycythemia vera. N. Engl. J. Med. 2013, 368, 22-33. [CrossRef] [PubMed]

70. Saban, N.; Bujak, M. Hydroxyurea and hydroxamic acid derivatives as antitumor drugs. Cancer Chemother. Pharmacol. 2009, 64, 213-221. [CrossRef]

71. Barbui, T.; Barosi, G.; Birgegard, G.; Cervantes, F.; Finazzi, G.; Griesshammer, M.; Harrison, C.; Hasselbalch, H.C.; Hehlmann R.; Hoffman, R.; et al. Philadelphia-negative classical myeloproliferative neoplasms: Critical concepts and management recommendations from European LeukemiaNet. J. Clin. Oncol. Off. J. Am. Soc. Clin. Oncol. 2011, 29, 761-770. [CrossRef]

72. Alvarez-Larran, A.; Pereira, A.; Cervantes, F.; Arellano-Rodrigo, E.; Hernandez-Boluda, J.C.; Ferrer-Marin, F.; Angona, A.; Gomez, M.; Muina, B.; Guillen, H.; et al. Assessment and prognostic value of the European LeukemiaNet criteria for clinicohematologic response, resistance, and intolerance to hydroxyurea in polycythemia vera. Blood 2012, 119, 1363-1369. [CrossRef]

73. Alvarez-Larran, A.; Kerguelen, A.; Hernandez-Boluda, J.C.; Perez-Encinas, M.; Ferrer-Marin, F.; Barez, A.; Martinez-Lopez, J.; Cuevas, B.; Mata, M.I.; Garcia-Gutierrez, V.; et al. Frequency and prognostic value of resistance/intolerance to hydroxycarbamide in 890 patients with polycythaemia vera. Br. J. Haematol. 2016, 172, 786-793. [CrossRef]

74. Gisslinger, H.; Klade, C.; Georgiev, P.; Krochmalczyk, D.; Gercheva-Kyuchukova, L.; Egyed, M.; Rossiev, V.; Dulicek, P.; Illes, A.; Pylypenko, H.; et al. Ropeginterferon alfa-2b versus standard therapy for polycythaemia vera (PROUD-PV and CONTINUATION-PV): A randomised, non-inferiority, phase 3 trial and its extension study. Lancet Haematol. 2020, 7, e196-e208. [CrossRef]

75. Hasselbalch, H.C.; Skov, V.; Kjær, L.; Ellervik, C.; Poulsen, A.; Poulsen, T.D.; Nielsen, C.H. COVID-19 as a mediator of in-terferon deficiency and hyperinflammation: Rationale for the use of JAK1/2 inhibitors in combination with interferon. Cy-Tokine Growth Factor Rev. 2021, 60, 28-45. [CrossRef]

76. Zahran, A.M.; Nafady, A.; Saad, K.; Hetta, H.F.; Abdallah, A.M.; Abdel-Aziz, S.M.; Embaby, M.M.; Abo Elgheet, A.M.; Dar-wish, S.F.; Abo-Elela, M.G.M.; et al. Effect of Hydroxyurea Treatment on the Inflammatory Markers Among Children With Sickle Cell Disease. Clin. Appl. Thromb./Hemost. Off. J. Int. Acad. Clin. Appl. Thromb./Hemost. 2020, 26, 1-7. [CrossRef]

77. Guarda, C.C.; Silveira-Mattos, P.S.M.; Yahouédéhou, S.; Santiago, R.P.; Aleluia, M.M.; Figueiredo, C.V.B.; Fiuza, L.M.; Carvalho, S.P.; Oliveira, R.M.; Nascimento, V.M.L.; et al. Hydroxyurea alters circulating monocyte subsets and dampens its inflammatory potential in sickle cell anemia patients. Sci. Rep. 2019, 9, 14829. [CrossRef]

78. Lori, F.; Lisziewicz, J. Hydroxyurea: Overview of clinical data and antiretroviral and immunomodulatory effects. Antivir. Ther. 1999, 4 (Suppl. 3), 101-108. [PubMed]

79. Palandri, F.; Piciocchi, A.; De Stefano, V.; Breccia, M.; Finazzi, G.; Iurlo, A.; Fazi, P.; Soddu, S.; Martino, B.; Siragusa, S.; et al. How the coronavirus pandemic has affected the clinical management of Philadelphia-negative chronic myeloproliferative neoplasms in Italy-a GIMEMA MPN WP survey. Leukemia 2020, 34, 2805-2808. [CrossRef]

80. Kiladjian, J.J.; Mesa, R.A.; Hoffman, R. The renaissance of interferon therapy for the treatment of myeloid malignancies. Blood 2011, 117, 4706-4715. [CrossRef] [PubMed]

81. Hasselbalch, H.C. A new era for IFN- $\alpha$ in the treatment of Philadelphia-negative chronic myeloproliferative neoplasms. Expert Rev. Hematol. 2011, 4, 637-655. [CrossRef] [PubMed]

82. Samuel, C.E. Antiviral actions of interferons. Clin. Microbiol. Rev. 2001, 14, 778-809. [CrossRef] [PubMed]

83. Nile, S.H.; Nile, A.; Qiu, J.; Li, L.; Jia, X.; Kai, G. COVID-19: Pathogenesis, cytokine storm and therapeutic potential of interferons. Cytokine Growth Factor Rev. 2020, 53, 66-70. [CrossRef] [PubMed] 
84. Sainz, B., Jr.; Mossel, E.C.; Peters, C.J.; Garry, R.F. Interferon-beta and interferon-gamma synergistically inhibit the replication of severe acute respiratory syndrome-associated coronavirus (SARS-CoV). Virology 2004, 329, 11-17. [CrossRef]

85. DeBaun, M.R. Initiating adjunct low-dose hydroxyurea therapy for stroke prevention in children with SCA during the COVID-19 pandemic. Blood 2020, 135, 1997-1999. [CrossRef]

86. European Medicines Agency. COVID-19 Pandemic. 2021. Available online: https://www.ema.europa.eu/en (accessed on 21 May 2021).

87. National Comprehensive Cancer Network. Recorded Patient Webinar: Myeloproliferative Neoplasms (MPN). 2021. Available online: https:/ / www.nccn.org/patientresources/patient-resources/myeloproliferative-neoplasms-mpn (accessed on 21 May 2021).

88. Verstovsek, S.; Mesa, R.A.; Gotlib, J.; Levy, R.S.; Gupta, V.; DiPersio, J.F.; Catalano, J.V.; Deininger, M.; Miller, C.; Silver, R.T.; et al. A double-blind, placebo-controlled trial of ruxolitinib for myelofibrosis. N. Engl. J. Med. 2012, 366, 799-807. [CrossRef]

89. Harrison, C.; Kiladjian, J.J.; Al-Ali, H.K.; Gisslinger, H.; Waltzman, R.; Stalbovskaya, V.; McQuitty, M.; Hunter, D.S.; Levy, R.; Knoops, L.; et al. JAK inhibition with ruxolitinib versus best available therapy for myelofibrosis. N. Engl. J. Med. 2012, 366, 787-798. [CrossRef]

90. Vannucchi, A.M.; Kiladjian, J.J.; Griesshammer, M.; Masszi, T.; Durrant, S.; Passamonti, F.; Harrison, C.N.; Pane, F.; Zachee, P.; Mesa, R.; et al. Ruxolitinib versus standard therapy for the treatment of polycythemia vera. N. Engl. J. Med. 2015, 372, 426-435. [CrossRef] [PubMed]

91. Kiladjian, J.J.; Zachee, P.; Hino, M.; Pane, F.; Masszi, T.; Harrison, C.N.; Mesa, R.; Miller, C.B.; Passamonti, F.; Durrant, S.; et al. Long-term efficacy and safety of ruxolitinib versus best available therapy in polycythaemia vera (RESPONSE): 5-year follow up of a phase 3 study. Lancet Haematol. 2020, 7, e226-e237. [CrossRef]

92. Passamonti, F.; Griesshammer, M.; Palandri, F.; Egyed, M.; Benevolo, G.; Devos, T.; Callum, J.; Vannucchi, A.M.; Sivgin, S.; Bensasson, C.; et al. Ruxolitinib for the treatment of inadequately controlled polycythaemia vera without splenomegaly (RESPONSE-2): A randomised, open-label, phase 3b study. Lancet Oncol. 2017, 18, 88-99. [CrossRef]

93. Griesshammer, M.; Saydam, G.; Palandri, F.; Benevolo, G.; Egyed, M.; Callum, J.; Devos, T.; Sivgin, S.; Guglielmelli, P.; Bensasson, C.; et al. Ruxolitinib for the treatment of inadequately controlled polycythemia vera without splenomegaly: 80-week follow-up from the RESPONSE-2 trial. Ann. Hematol. 2018, 97, 1591-1600. [CrossRef] [PubMed]

94. Elli, E.M.; Barate, C.; Mendicino, F.; Palandri, F.; Palumbo, G.A. Mechanisms Underlying the Anti-inflammatory and Immunosuppressive Activity of Ruxolitinib. Front. Oncol. 2019, 9, 1186. [CrossRef]

95. Palandri, F.; Polverelli, N.; Catani, L.; Vianelli, N. Ruxolitinib-associated tuberculosis: A case of successful ruxolitinib rechallenge. Ann. Hematol. 2015, 94, 519-520. [CrossRef]

96. Colomba, C.; Rubino, R.; Siracusa, L.; Lalicata, F.; Trizzino, M.; Titone, L.; Tolomeo, M. Disseminated tuberculosis in a patient treated with a JAK2 selective inhibitor: A case report. BMC Res. Notes 2012, 5, 552. [CrossRef]

97. Goldberg, R.A.; Reichel, E.; Oshry, L.J. Bilateral toxoplasmosis retinitis associated with ruxolitinib. N. Engl. J. Med. 2013, 369, 681-683. [CrossRef] [PubMed]

98. Pálmason, R.; Lindén, O.; Richter, J. Case-report: EBV driven lymphoproliferative disorder associated with Ruxolitinib. BMC Hematol. 2015, 15, 10. [CrossRef]

99. Tong, L.X.; Jackson, J.; Kerstetter, J.; Worswick, S.D. Reactivation of herpes simplex virus infection in a patient undergoing ruxolitinib treatment. J. Am. Acad. Dermatol. 2014, 70, e59-e60. [CrossRef]

100. von Hofsten, J.; Johnsson Forsberg, M.; Zetterberg, M. Cytomegalovirus Retinitis in a Patient Who Received Ruxolitinib. N. Engl. J. Med. 2016, 374, 296-297. [CrossRef]

101. Caocci, G.; Murgia, F.; Podda, L.; Solinas, A.; Atzeni, S.; La Nasa, G. Reactivation of hepatitis B virus infection following ruxolitinib treatment in a patient with myelofibrosis. Leukemia 2014, 28, 225-227. [CrossRef] [PubMed]

102. Wysham, N.G.; Sullivan, D.R.; Allada, G. An opportunistic infection associated with ruxolitinib, a novel janus kinase 1,2 inhibitor. Chest 2013, 143, 1478-1479. [CrossRef] [PubMed]

103. Lee, S.C.; Feenstra, J.; Georghiou, P.R. Pneumocystis jiroveci pneumonitis complicating ruxolitinib therapy. BMJ Case Rep. 2014, 2014, bcr2014204950. [CrossRef] [PubMed]

104. Wathes, R.; Moule, S.; Milojkovic, D. Progressive multifocal leukoencephalopathy associated with ruxolitinib. N. Engl. J. Med. 2013, 369, 197-198. [CrossRef]

105. Chen, C.C.; Chen, Y.Y.; Huang, C.E. Cryptococcal meningoencephalitis associated with the long-term use of ruxolitinib. Ann. Hematol. 2016, 95, 361-362. [CrossRef]

106. Heine, A.; Brossart, P.; Wolf, D. Ruxolitinib is a potent immunosuppressive compound: Is it time for anti-infective prophylaxis? Blood 2013, 122, 3843-3844. [CrossRef]

107. Mehta, P.; McAuley, D.F.; Brown, M.; Sanchez, E.; Tattersall, R.S.; Manson, J.J. COVID-19: Consider cytokine storm syndromes and immunosuppression. Lancet 2020, 395, 1033-1034. [CrossRef]

108. Pedersen, S.F.; Ho, Y.C. SARS-CoV-2: A storm is raging. J. Clin. Investig. 2020, 130, 2202-2205. [CrossRef] [PubMed]

109. Villarino, A.V.; Kanno, Y.; Ferdinand, J.R.; O'Shea, J.J. Mechanisms of Jak/STAT signaling in immunity and disease. J. Immunol. 2015, 194, 21-27. [CrossRef] [PubMed]

110. Seif, F.; Khoshmirsafa, M.; Aazami, H.; Mohsenzadegan, M.; Sedighi, G.; Bahar, M. The role of JAK-STAT signaling pathway and its regulators in the fate of T helper cells. Cell Commun. Signal. CCS 2017, 15, 23. [CrossRef] 
111. Velazquez-Salinas, L.; Verdugo-Rodriguez, A.; Rodriguez, L.L.; Borca, M.V. The Role of Interleukin 6 During Viral Infections. Front. Microbiol. 2019, 10, 1057. [CrossRef] [PubMed]

112. Vannucchi, A.M.; Sordi, B.; Morettini, A.; Nozzoli, C.; Poggesi, L.; Pieralli, F.; Bartoloni, A.; Atanasio, A.; Miselli, F.; Paoli, C.; et al. Compassionate use of JAK1/2 inhibitor ruxolitinib for severe COVID-19: A prospective observational study. Leukemia 2021, 35, 1121-1133. [CrossRef]

113. Connors, M.; Graham, B.S.; Lane, H.C.; Fauci, A.S. SARS-CoV-2 Vaccines: Much Accomplished, Much to Learn. Ann. Intern. Med. 2021, 174, 687-690. [CrossRef]

114. Petrosillo, N.; Viceconte, G.; Ergonul, O.; Ippolito, G.; Petersen, E. COVID-19, SARS and MERS: Are they closely related? Clin. Microbiol. Infect. Off. Publ. Eur. Soc. Clin. Microbiol. Infect. Dis. 2020, 26, 729-734. [CrossRef]

115. Du, L.; He, Y.; Zhou, Y.; Liu, S.; Zheng, B.J.; Jiang, S. The spike protein of SARS-CoV-A target for vaccine and therapeutic development. Nat. Rev. Microbiol. 2009, 7, 226-236. [CrossRef]

116. Du, L.; Zhao, G.; He, Y.; Guo, Y.; Zheng, B.J.; Jiang, S.; Zhou, Y. Receptor-binding domain of SARS-CoV spike protein induces long-term protective immunity in an animal model. Vaccine 2007, 25, 2832-2838. [CrossRef]

117. Khan, I.; Ahmed, Z.; Sarwar, A.; Jamil, A.; Anwer, F. The Potential Vaccine Component for COVID-19: A Comprehensive Review of Global Vaccine Development Efforts. Cureus 2020, 12, e8871. [CrossRef] [PubMed]

118. Baden, L.R.; El Sahly, H.M.; Essink, B.; Kotloff, K.; Frey, S.; Novak, R.; Diemert, D.; Spector, S.A.; Rouphael, N.; Creech, C.B.; et al. Efficacy and Safety of the mRNA-1273 SARS-CoV-2 Vaccine. N. Engl. J. Med. 2021, 384, 403-416. [CrossRef] [PubMed]

119. Polack, F.P.; Thomas, S.J.; Kitchin, N.; Absalon, J.; Gurtman, A.; Lockhart, S.; Perez, J.L.; Pérez Marc, G.; Moreira, E.D.; Zerbini, C.; et al. Safety and Efficacy of the BNT162b2 mRNA Covid-19 Vaccine. N. Engl. J. Med. 2020, 383, 2603-2615. [CrossRef]

120. Benenson, S.; Oster, Y.; Cohen, M.J.; Nir-Paz, R. BNT162b2 mRNA Covid-19 Vaccine Effectiveness among Health Care Workers. N. Engl. J. Med. 2021, 384, 1775-1777. [CrossRef]

121. Dagan, N.; Barda, N.; Kepten, E.; Miron, O.; Perchik, S.; Katz, M.A.; Hernán, M.A.; Lipsitch, M.; Reis, B.; Balicer, R.D. BNT162b2 mRNA Covid-19 Vaccine in a Nationwide Mass Vaccination Setting. N. Engl. J. Med. 2021, 384, 1412-1423. [CrossRef]

122. Rinott, E.; Youngster, I.; Lewis, Y.E. Reduction in COVID-19 Patients Requiring Mechanical Ventilation Following Implementation of a National COVID-19 Vaccination Program-Israel, December 2020-February 2021. MMWR Morb. Mortal. Wkly. Rep. 2021, 70, 326-328. [CrossRef]

123. Thompson, M.G.; Burgess, J.L.; Naleway, A.L.; Tyner, H.L.; Yoon, S.K.; Meece, J.; Olsho, L.E.W.; Caban-Martinez, A.J.; Fowlkes, A.; Lutrick, K.; et al. Interim Estimates of Vaccine Effectiveness of BNT162b2 and mRNA-1273 COVID-19 Vaccines in Preventing SARS-CoV-2 Infection Among Health Care Personnel, First Responders, and Other Essential and Frontline Workers-Eight U.S. Locations, December 2020-March 2021. MMWR Morb. Mortal. Wkly. Rep. 2021, 70, 495-500. [CrossRef]

124. Sadoff, J.; Le Gars, M.; Shukarev, G.; Heerwegh, D.; Truyers, C.; de Groot, A.M.; Stoop, J.; Tete, S.; Van Damme, W.; Leroux-Roels, I.; et al. Interim Results of a Phase 1-2a Trial of Ad26.COV2.S Covid-19 Vaccine. N. Engl. J. Med. 2021, 384, 1824-1835. [CrossRef]

125. Janssen Biotech, Inc. FDA Briefing Document. Janssen Ad26.COV2.S Vaccine for the Prevention of COVID-19. In: Vaccines and Related Biological Products Advisory Committee Meeting. 26 February 2021. Available online: https://www.fda.gov/media/14 6217/ download (accessed on 26 May 2021).

126. Voysey, M.; Clemens, S.A.C.; Madhi, S.A.; Weckx, L.Y.; Folegatti, P.M.; Aley, P.K.; Angus, B.; Baillie, V.L.; Barnabas, S.L.; Bhorat, Q.E.; et al. Safety and efficacy of the ChAdOx1 nCoV-19 vaccine (AZD1222) against SARS-CoV-2: An interim analysis of four randomised controlled trials in Brazil, South Africa, and the UK. Lancet 2021, 397, 99-111. [CrossRef]

127. Knoll, M.D.; Wonodi, C. Oxford-AstraZeneca COVID-19 vaccine efficacy. Lancet 2021, 397, 72-74. [CrossRef]

128. Østergaard, S.D.; Schmidt, M.; Horváth-Puhó, E.; Thomsen, R.W.; Sørensen, H.T. Thromboembolism and the Oxford-AstraZeneca COVID-19 vaccine: Side-effect or coincidence? Lancet 2021, 397, 1441-1443. [CrossRef]

129. Bonaventura, A.; Vecchié, A.; Dagna, L.; Martinod, K.; Dixon, D.L.; Van Tassell, B.W.; Dentali, F.; Montecucco, F.; Massberg, S.; Levi, M.; et al. Endothelial dysfunction and immunothrombosis as key pathogenic mechanisms in COVID-19. Nat. Rev. Immunol. 2021, 21, 319-329. [CrossRef] [PubMed]

130. Greinacher, A.; Thiele, T.; Warkentin, T.E.; Weisser, K.; Kyrle, P.A.; Eichinger, S. Thrombotic Thrombocytopenia after ChAdOx1 nCov-19 Vaccination. N. Engl. J. Med. 2021, 384, 2092-2101. [CrossRef] [PubMed]

131. Schultz, N.H.; Sørvoll, I.H.; Michelsen, A.E.; Munthe, L.A.; Lund-Johansen, F.; Ahlen, M.T.; Wiedmann, M.; Aamodt, A.H.; Skattør, T.H.; Tjønnfjord, G.E.; et al. Thrombosis and Thrombocytopenia after ChAdOx1 nCoV-19 Vaccination. N. Engl. J. Med. 2021, 384, 2124-2130. [CrossRef]

132. Scully, M.; Singh, D.; Lown, R.; Poles, A.; Solomon, T.; Levi, M.; Goldblatt, D.; Kotoucek, P.; Thomas, W.; Lester, W. Pathologic Antibodies to Platelet Factor 4 after ChAdOx1 nCoV-19 Vaccination. N. Engl. J. Med. 2021, 384, 2202-2211. [CrossRef]

133. See, I.; Su, J.R.; Lale, A.; Woo, E.J.; Guh, A.Y.; Shimabukuro, T.T.; Streiff, M.B.; Rao, A.K.; Wheeler, A.P.; Beavers, S.F.; et al. US Case Reports of Cerebral Venous Sinus Thrombosis With Thrombocytopenia After Ad26.COV2.S Vaccination, March 2 to April 21, 2021. JAMA 2021, 325, 2448-2456. [CrossRef]

134. Sangli, S.; Virani, A.; Cheronis, N.; Vannatter, B.; Minich, C.; Noronha, S.; Bhagavatula, R.; Speredelozzi, D.; Sareen, M.; Kaplan, R.B. Thrombosis with Thrombocytopenia After the Messenger RNA-1273 Vaccine. Ann. Intern. Med. 2021, 244. [CrossRef]

135. Gresele, P.; Momi, S.; Marcucci, R.; Ramundo, F.; De Stefano, V.; Tripodi, A. Interactions of adenoviruses with platelets and coagulation and the vaccine-associated autoimmune thrombocytopenia thrombosis syndrome. Haematologica 2021. epub ahead of print. [CrossRef] 
136. Marcucci, R.; Marietta, M. Vaccine-induced thrombotic thrombocytopenia: The elusive link between thrombosis and adenovirusbased SARS-CoV-2 vaccines. Intern. Emerg. Med. 2021, 16, 1113-1119. [CrossRef]

137. Wise, J. Covid-19: European countries suspend use of Oxford-AstraZeneca vaccine after reports of blood clots. BMJ Clin. Res. 2021, 372, n699. [CrossRef]

138. Marks, P. Joint CDC and FDA Statement on Johnson \& Johnson COVID-19 Vaccine. FDA 2021. Available online: https: //www.fda.gov/news-events/press-announcements/joint-cdc-and-fda-statement-johnson-johnson-covid-19-vaccine (accessed on 26 May 2021).

139. Passamonti, F.; Romano, A.; Salvini, M.; Merli, F.; Porta, M.G.D.; Bruna, R.; Coviello, E.; Romano, I.; Cairoli, R.; Lemoli, R.; et al. COVID-19 elicits an impaired antibody response against SARS-CoV-2 in patients with haematological malignancies. Br. J. Haematol. 2021, 1-7. [CrossRef]

140. Rubin, L.G.; Levin, M.J.; Ljungman, P.; Davies, E.G.; Avery, R.; Tomblyn, M.; Bousvaros, A.; Dhanireddy, S.; Sung, L.; Keyserling, H.; et al. 2013 IDSA clinical practice guideline for vaccination of the immunocompromised host. Clin. Infect. Dis. Off. Publ. Infect. Dis. Soc. Am. 2014, 58, 309-318. [CrossRef]

141. Koschmieder, S.; Mughal, T.I.; Hasselbalch, H.C.; Barosi, G.; Valent, P.; Kiladjian, J.J.; Jeryczynski, G.; Gisslinger, H.; Jutzi, J.S.; Pahl, H.L.; et al. Myeloproliferative neoplasms and inflammation: Whether to target the malignant clone or the inflammatory process or both. Leukemia 2016, 30, 1018-1024. [CrossRef]

142. Mikulska, M.; Cesaro, S.; de Lavallade, H.; Di Blasi, R.; Einarsdottir, S.; Gallo, G.; Rieger, C.; Engelhard, D.; Lehrnbecher, T.; Ljungman, P.; et al. Vaccination of patients with haematological malignancies who did not have transplantations: Guidelines from the 2017 European Conference on Infections in Leukaemia (ECIL 7). Lancet Infect. Dis. 2019, 19, e188-e199. [CrossRef]

143. Pimpinelli, F.; Marchesi, F.; Piaggio, G.; Giannarelli, D.; Papa, E.; Falcucci, P.; Pontone, M.; Di Martino, S.; Laquintana, V.; La Malfa, A.; et al. Fifth-week immunogenicity and safety of anti-SARS-CoV-2 BNT162b2 vaccine in patients with multiple myeloma and myeloproliferative malignancies on active treatment: Preliminary data from a single institution. J. Hematol. Oncol. 2021, 14, 81. [CrossRef]

144. Harrington, P.; de Lavallade, H.; Doores, K.J.; O’Reilly, A.; Seow, J.; Graham, C.; Lechmere, T.; Radia, D.; Dillon, R.; Shanmugharaj, Y.; et al. Single dose of BNT162b2 mRNA vaccine against SARS-CoV-2 induces high frequency of neutralising antibody and polyfunctional T-cell responses in patients with myeloproliferative neoplasms. Leukemia 2021, 1-5. [CrossRef]

145. Maneikis, K.; Šablauskas, K.; Ringelevičiūtè, U.; Vaitekènaitè, V.; Čekauskienè, R.; Kryžauskaitè, L.; Naumovas, D.; Banys, V.; Pečeliūnas, V.; Beinortas, T.; et al. Immunogenicity of the BNT162b2 COVID-19 mRNA vaccine and early clinical outcomes in patients with haematological malignancies in Lithuania: A national prospective cohort study. Lancet Haematol. 2021 , 8, e583-e592. [CrossRef]

146. Guglielmelli, P.; Mazzoni, A.; Maggi, L.; Kiros, S.T.; Zammarchi, L.; Pilerci, S.; Rocca, A.; Spinicci, M.; Borella, M.; Bartoloni, A.; et al. Impaired response to first SARS-CoV-2 dose vaccination in myeloproliferative neoplasm patients receiving ruxolitinib. Am. J. Hematol. 2021. epub ahead of print. [CrossRef]

147. Herzog Tzarfati, K.; Gutwein, O.; Apel, A.; Rahimi-Levene, N.; Sadovnik, M.; Harel, L.; Benveniste-Levkovitz, P.; Bar Chaim, A.; Koren-Michowitz, M. BNT162b2 COVID-19 vaccine is significantly less effective in patients with hematologic malignancies. Am. J. Hematol. 2021, 96, 1195-1203. [CrossRef]

148. Keech, C.; Albert, G.; Cho, I.; Robertson, A.; Reed, P.; Neal, S.; Plested, J.S.; Zhu, M.; Cloney-Clark, S.; Zhou, H.; et al. Phase 1-2 Trial of a SARS-CoV-2 Recombinant Spike Protein Nanoparticle Vaccine. N. Engl. J. Med. 2020, 383, 2320-2332. [CrossRef]

149. Logunov, D.Y.; Dolzhikova, I.V.; Shcheblyakov, D.V.; Tukhvatulin, A.I.; Zubkova, O.V.; Dzharullaeva, A.S.; Kovyrshina, A.V.; Lubenets, N.L.; Grousova, D.M.; Erokhova, A.S.; et al. Safety and efficacy of an rAd26 and rAd5 vector-based heterologous prime-boost COVID-19 vaccine: An interim analysis of a randomised controlled phase 3 trial in Russia. Lancet 2021, 397, 671-681. [CrossRef]

150. Chowdhury, O.; Bruguier, H.; Mallett, G.; Sousos, N.; Crozier, K.; Allman, C.; Eyre, D.; Lumley, S.; Strickland, M.; Karali, C.S.; et al. Impaired antibody response to COVID-19 vaccination in patients with chronic myeloid neoplasms. Br. J. Haematol. 2021, 194, 1010-1015. [CrossRef] [PubMed]

151. Board on Health Care Services; Institute of Medicine. The Role of Telehealth in an Evolving Health Care Environment: Workshop Summary; National Academies Press: Washington, DC, USA, 2012. [CrossRef]

152. Powell, R.E.; Henstenburg, J.M.; Cooper, G.; Hollander, J.E.; Rising, K.L. Patient Perceptions of Telehealth Primary Care Video Visits. Ann. Fam. Med. 2017, 15, 225-229. [CrossRef] [PubMed]

153. Chen, Y.Y.; Guan, B.S.; Li, Z.K.; Li, X.Y. Effect of telehealth intervention on breast cancer patients' quality of life and psychological outcomes: A meta-analysis. J. Telemed. Telecare 2018, 24, 157-167. [CrossRef] [PubMed]

154. Omboni, S. Telemedicine During the COVID-19 in Italy: A Missed Opportunity? Telemed. J. e-Health Off. J. Am. Telemed. Assoc. 2020, 26, 973-975. [CrossRef]

155. Hollander, J.E.; Carr, B.G. Virtually Perfect? Telemedicine for Covid-19. N. Engl. J. Med. 2020, 382, 1679-1681. [CrossRef]

156. Duffy, S.; Lee, T.H. In-Person Health Care as Option B. N. Engl. J. Med. 2018, 378, 104-106. [CrossRef]

157. Lurie, N.; Carr, B.G. The Role of Telehealth in the Medical Response to Disasters. JAMA Intern. Med. 2018, 178, 745-746. [CrossRef]

158. Greenhalgh, T.; Wherton, J.; Shaw, S.; Morrison, C. Video consultations for covid-19. BMJ Clin. Res. 2020, 368, m998. [CrossRef]

159. Dorsey, E.R.; Topol, E.J. Telemedicine 2020 and the next decade. Lancet 2020, 395, 859. [CrossRef] 
160. Kadir, M.A. Role of telemedicine in healthcare during COVID-19 pandemic in developing countries. Telehealth Med. Today 2020, 5. [CrossRef]

161. Pavord, S.; Thachil, J.; Hunt, B.J.; Murphy, M.; Lowe, G.; Laffan, M.; Makris, M.; Newland, A.C.; Provan, D.; Grainger, J.D.; et al. Practical guidance for the management of adults with immune thrombocytopenia during the COVID-19 pandemic. Br. J. Haematol. 2020, 189, 1038-1043. [CrossRef]

162. Willan, J.; King, A.J.; Hayes, S.; Collins, G.P.; Peniket, A. Care of haematology patients in a COVID-19 epidemic. Br. J. Haematol. 2020, 189, 241-243. [CrossRef]

163. Palandri, F.; Bartoletti, D.; Giaquinta, S.; D’Ambrosio, F.; Auteri, G.; Sutto, E.; Catani, L.; Vianelli, N.; Cavo, M. Telemedicine in patients with haematological diseases during the coronavirus disease 2019 (COVID-19) pandemic: Selection criteria and patients' satisfaction. Br. J. Haematol. 2021, 192, e48-e51. [CrossRef] 